\title{
Assessing the Impact of Field- of-Use Restrictions in Patent Licensing Agreements: The Ethical Pharmaceutical Industry in the United States, 1950-1962
}

\author{
MAR CEBRIÁN VILLAR \\ SANTIAGO LÓPEZ GARCÍA
}

There are a number of strategies employed by companies to limit price competition, including patenting. This article investigates patent licensing restrictions as a strategy to erode price competition, using mainly information gleaned from the 1960-1962 Kefauver Committee hearings. The article deals with the pharmaceutical industry, which is one of the few sectors in which patents are essential to the development and introduction of innovations. The current study adds to a body of literature that has yielded mixed results with respect to the role of patents in this industry. The main contribution of this research is that restrictive licensing clauses, specifically field-of-use restrictions, are found to be

(C) The Author 2017. Published by Cambridge University Press on behalf of the Business History Conference.

doi:10.1017/eso.2016.43

Published online February 20, 2017

Mar Cebrián Villar is associate professor in the Department of Economics and Economic History and a member of the Instituto Universitario de Estudios de la Ciencia y la Tecnología, University of Salamanca. Contact information: Facultad de Economía y Empresa, Edificio FES, Campus Miguel de Unamuno, Universidad de Salamanca, Salamanca 37007. E-mail: marcebrian@usal.es

Santiago López García is associate professor in the Department of Economics and Economic History and a member of the Instituto Universitario de Estudios de la Ciencia y la Tecnología, University of Salamanca. Contact information: Facultad de Economía y Empresa, Edificio FES, Campus Miguel de Unamuno, Universidad de Salamanca, Salamanca 37007. E-mail: marcebrian@usal.es

We acknowledge the financial support from the Ministry of Economy and Competitiveness, Award number HAR2013-40760-R, subprogram HIST. The first author thanks Professor Antonio Feros for his help during her stay at the University of Pennsylvania. Preliminary versions were presented to the European Business History Association Congresses held in 2013 in Uppsala, Sweden, and in 2014 in Utrecht, The Netherlands. We would like to thank conference participants and two anonymous referees for their helpful comments and suggestions. 
relevant in eroding price competition in the institutional market. However, in the retail ethical market, price competition was absent even when no field-of-use restrictions were included in licensing contracts, although product competition was relevant between patented drugs.

The pharmaceutical industry is often put forward as the best example of the need for patents. Patents are extremely important in reaping the benefits of innovation in the pharmaceutical industry due to two factors: the high cost of discovering, developing, and gaining regulatory approval for a new medicine, and the very low imitation costs relative to the expenditures incurred by the innovator in drug discovery and development. ${ }^{1}$ Many laboratories can replicate drugs because it is relatively easy to imitate a product once it is available on the market and after researchers analyze its composition. Thus, the pharmaceutical sector depends heavily on the patent system to protect innovative designs from imitation. ${ }^{2}$ It is only through enforceable patent protection that drug companies can generate sufficient revenues to undertake the costly and risky research and development (R\&D) that makes the introduction of new products possible. In a few sectors, patents are essential to the development and introduction of innovations, and the pharmaceutical sector is one such example. ${ }^{3}$

However, patents can also be employed as a strategy to harm the competitive process by adopting measures to restrict price competition; to extend the breadth and duration of their patent protection; or to delay, discourage, or block the market entry of competing products (e.g., patents thickets, secondary patents, and defensive patents). ${ }^{4}$

1. See, e.g., Mansfield, "Patents and Innovation"; Penin, "Patents Versus Ex Post Rewards"; Slinn, "Patents and the UK Pharmaceutical Industry." Sarett has shown that the average development costs per new chemical entity were \$1.2 million in 1962 and \$11.5 million in 1973. Sarett, "FDA Regulations." For the relationship between science and the industry in the period 1890-1930, see Liebenau, Medical Science.

2. Temin, Taking Your Medicine; Levin et al., "Appropriating the Returns"; Grabowski and Vernon, "Substitution Laws"; Gambardella, Science and Innovation.

3. Silberston argues that the only industry in which patents are essential is the pharmaceutical industry. Silberston, Economic Importance of Patents.

4. Ellison and Ellison, "Strategic Entry Deterrence"; Boldrin and Levine, Against Intellectual Monopoly; Comanor, "Research and Competitive Product Differentiation"; Steele, "Monopoly and Competition.” For an illustrative example of how chemical firms in Germany employed patents to block competition from others manufacturers, both at home and abroad, see Liebenau, "Patents and the Chemical Industry.” One common current practice is so-called evergreening, in which pharmaceutical patent owners use the law to retain rent from their patents by taking out new patents to extend their intellectual property rights. 
According to Henry Steele in a seminal work, firms use patents not only as a way to protect their innovations but also as a strategy to increase their market share and to limit price competition. ${ }^{5}$ For instance, patent or patent application holders may take measures such as cross-licensing agreements, licensing, and litigation settlements to restrict competition. ${ }^{6}$ Specifically, to maximize the value of an innovation, patentees usually include field-of-use restrictions in licensing and cross-licensing agreements. These field-of-use restrictions are provisions under which licensees are prohibited from selling drugs in bulk form; that is, the form in which drugs are manufactured prior to being packaged into finished dosage form. This means that licensees can only sell patented drugs in finished dosage form, packaged form, or specialty form; that is, pharmaceutical drug products in the form in which they are marketed for use such as pills, tablets, capsules, or syrup. In this way, licensees prevent competitors from converting the bulk drug into finished and packaged tablets-tableting, bottling, packaging, and labeling — and from selling them either generically or under their own brand names and at their own prices.

The inclusion of a field-of-use restriction was commonplace in the agreements signed by big pharmaceutical firms in the period discussed in this article. ${ }^{7}$ The patent holder usually decided not to license to small firms, so this type of restriction blocked small competitors from accessing the active ingredient in bulk form and from selling the drugs at significantly lower prices than those of large firms. This is because, on the one hand, smaller firms had a cost advantage over large companies because they did not have to recoup extensive $\mathrm{R} \& \mathrm{D}$ costs and the costs of advertising, promotion, and marketing. On the other hand, these costs were entry barriers for smaller companies into the prescription retail market. If the patent licensing agreement included a field-of-use restriction, small firms could only buy the drug exclusively in finished packaged form at a higher price. In selling drugs not in bulk form but under a brand name, big firms

The phrase refers to threats made to competitors regarding a brand-name manufacturer's tactical use of pharmaceutical patents. Manufacturers of a particular drug use evergreening to restrict or prevent competition from manufacturers of generic drugs. See Faunce and Lexchin, “'Linkage’ Pharmaceutical Evergreening in Canada and Australia."

5. Steele, "Patent Restrictions."

6. For the need to resolve intellectual property disputes, see Lanjouw and Schankerman, "Protecting Intellectual Property Rights"; Gallini, "Economics of Patents." For the use of the litigation process as an opportunity to engage in strategic behavior, see Meurer, "Settlement of Patent Litigation."

7. Big companies were those that were fully integrated and had extensive research facilities, growing medical departments, and significant marketing capability. 
had to spend much more money on costly promotional campaigns. This expense ultimately made the drugs more expensive, because the big firms had to recover their marketing investment from the consumer. The inclusion of field-of-use restrictions in patent licensing agreements theoretically provided a solution that reduced competition because these restrictions constrained price competition from small companies.

This article focuses on the ethical pharmaceutical industry in the United States-particularly the tranquilizer sector-in the 1950s and early 1960s, when psychopharmacology in the treatment of mental illness really took off. ${ }^{8}$ In this period of exponential growth of the pharmaceutical industry, large manufacturers challenged each other vigorously in product competition in order to gain a significant market share through their major investments in R\&D and marketing. Moreover, there was rapid growth in the number of new medicines to treat mental illness, sustained efforts by pharmaceutical firms to develop markets for their products, and rising demand for drugs. Consumers were optimistic about the possibilities of pharmaceutical science, and this culture led to increasing demand among patients despite the high prices. ${ }^{9}$

Concerns over the consequences of excessively high consumer pricing arose in the 1930s when inflation and its consequences for consumers became increasingly important issues in U.S. politics. It was in this context that economic New Dealers promoted government price control as a way of preventing under-consumption. In particular, by the late 1950s, ${ }^{10}$ Congressional Democrats, the Federal Trade Commission (FTC), consumer groups, and some physicians became preoccupied with the high costs of prescription drugs and the advertising practices of prescription drug firms.

8. The modern era of psychiatry and the so-called psychopharmacological revolution began with the discovery of the antipsychotic efficacy of chlorpromazine in 1955. López Muñoz et al., "History of the Discovery."

9. Tone, "Tranquilizers on Trial." From 1955 to 1960, the prescriptions of benzodiazepines (Miltown, Librium, and Valium) grew from zero to fifty million and implied a third of all psychiatric prescriptions drugs. Herzberg, Happy Pills in America, Appendix B, 209.

10. There was a postwar antimonopoly movement against oligopoly formation and in favor of the consumer. The Temporary National Economic Committee (TNEC), which held hearings between 1938 and 1941 on how to resolve the Great Depression, was conscious of the danger of big business. Among the most influential subcommittee staffers who aided Estes Kefauver in his investigations were Irene Till and John Wilson, who had been members of the FTC in the early 1950s and had worked together on the TNEC. In the mid-1950s, there were congressional and FTC investigations of the TNEC to study price fixing within the drug industry. See Bud, "Antibiotics, Big Business, and Consumers," 333-337; Williamson, Federal Antitrust Policy, 81-83. For an extended discussion of the relationship between antimonopoly and postwar consumer politics, see Scroop, "Faded Passion." 
In response to these concerns, the influential Democrat Senator Estes Kefauver started a Congressional investigation to study the price inflexibility of firms producing ethical drugs (or prescription drugs) in certain product categories that were characterized by their novelty and their importance to medicine. ${ }^{11}$ The high demand for drugs and the role of patents as a strategy to harm price competition came to public attention in late 1959 during Kefauver's hearings on the pharmaceutical industry. These hearings were an important development in the political history of prescription drugs and the first attempt to regulate their prices. ${ }^{12}$ In particular, the senator focused on the relationship between patent protection and high prescription drug prices in the U.S. pharmaceutical sector. On May 8, 1961, the Subcommittee on Antitrust and Monopoly of the Senate Judiciary Committee submitted its report on the ethical drugs industry ${ }^{13}$ (ethical drugs are discussed below). The report found that monopolistic drug pricing and abuses of patent privilege existed in the U.S. pharmaceutical industry. Following the hearings, Kefauver introduced a bill proposing several reforms, one of which was to restrict the use of pharmaceutical patents in order to increase competition and reduce the price of prescription drugs. His greatest legislative achievement was the passage of the Kefauver-Harris Drug Act of 1962, one of the most significant consumer safety laws of the twentieth century. Consequently, these hearings were fundamental to modern consumer politics and to the history of U.S. medicine after World War II.

11. The four groups studied in the Senate were antibiotics, antidiabetic drugs, tranquilizers, and corticosteroids. They represented 42 percent of all ethical drug sales in 1959. Prescription retail drugs were almost 70 percent of total drug sales at the end of the 1950s. Steele, "Patent Restrictions," 202.

12. Senator Kefauver, a Democrat from Tennessee, was the chairman of the Senate Subcommittee on Antitrust and Monopoly between 1957 and 1963; was against the Eisenhower administration for favoring big business; was the leading critic of monopoly in the postwar United States; and was concerned with the concentration of economic power, its effect on free enterprise and the political system, and the consequences of excessive prices for consumption. Scroop, "Faded Passion," 2, 7, 13-14. Doctors, retail druggists, and chambers of commerce pressured Kefauver to drop the drug investigation almost a year before the hearings started. During the hearings, representatives of the industry criticized the subcommittee. See Harris, Real Voice, 40.

13. The Durham-Humphrey Amendment of 1951 clarified the definition of prescription drugs and refills, changed the rules on how medicines could be marketed, and increased the protections of public health. These included that nonprescription drugs could be sold directly to consumers, the decision as to whether or not a drug that required a prescription legend rested with the manufacturer, and to know more about the regulation of prescription drugs before 1951. See Swann, "FDA and the Practice of Pharmacy." Just before World War II, the majority of U.S. producers still focused on nonprescription drugs; it was mainly in the 1950s when firms moved into prescription drugs. Chandler, Shaping the Industrial Century. 
This article is related to a growing body of literature focusing on the use of patent licensing as an instrument to limit competition. ${ }^{14}$ Specifically, our purpose is to study whether field-of-use restrictions in patent licensing contracts truly impeded price competition, as the Kefauver Committee concluded. The main source employed for this study was the original Senate Subcommittee Hearings on Antitrust and Monopoly during the period 1959-1961 (the Kefauver Committee). ${ }^{15}$ The article, in turn, links to other strands of the literature such as the joint importance of R\&D and marketing in the pharmaceutical industry.

We show how patent licensing restrictions, in fact, facilitated the erosion of price competition for prescription drugs only in the institutional market, in which lower prices were the major tool of competition. In this submarket, the presence of smaller firms as competitors stemmed from the fact that licensing contracts did not include fieldof-use restrictions, which forced leading pharmaceutical companies to enter into price competition in order to sell their patented drugs. However, because smaller firms would have had to buy the drug in finished dosage form if field-of-use restrictions were included, they then would also have had to pay a price similar to retail druggists. Therefore, they would be in no position to engage in sales to hospitals or to the government at lower prices. This strategy among leading firms-including field-of-use restrictions in patent licensing contracts to exclude small firms as competitors and thereby to preserve their market position-made no sense in the retail prescription submarket. There was no price competition in this submarket, and product differentiation and advertising were the major competitive weapons for increasing company market share. Smaller firms were not considered threats because the high costs of marketing and promoting a drug made it impossible for small sellers of generic-name products to obtain any significant share of the retail prescription market, even though they

14. See Taylor and Silberston, Economic Impact; Gallini, "Deterrence by Market Sharing”; Contractor, Licensing in International Strategy; Katz and Shapiro, "How to License Intangible Property"; Rockett, "Choosing the Competition"; Arora, "Patents, Licensing, and Market Structure."

15. On the decisive role of the Senate Committee Hearings in the history of American medicine after World War II, see Tobbell, "Who's Winning the Human Race?"”; McFadyen, Estes Kefauver and the Drug Industry; Harris, "Real Voice." The hearings constitute a rich source of primary source material on all aspects of American history. They include investigative files, and some contain police and other confidential reports or information that are difficult to find. In particular, they are a useful contribution to the literature on the pharmaceutical industry because there was no great quantitative information on pharmaceutical firms for this period outside the material published in the hearings. Steele, "Patent Restrictions," 202. For example, finding licensing contracts is highly difficult as there is no patent license database and patent licensing deals are almost always confidential. 
were able to sell drugs cheaper than brand-name drugs because they incurred lower costs (that is, no research and marketing costs).

Some previous drug industry studies have concluded that there was an absence of competition in the drug industry as a result of patent privilege. ${ }^{16}$ Other studies found significant rivalry based on factors other than price in the pharmaceutical industry. ${ }^{17}$ The evidence presented in this article indicates that before any conclusions can be drawn, it is crucial to define the concepts of competition and of the market-institutional or retail-in which firms sold their patented drugs. Thus, we demonstrate that there was indeed a lack of price competition in the retail market but not in the institutional market. In the first submarket, this was true even when smaller firms were present as competitors, although product competition was relevant among patented drugs. Finally, our research also provides empirical evidence of the following assertions:

- The grant of a patent does not always confer monopoly power to patentees.

- Patents are necessary as a means to stimulate investment in R\&D.

- In the pharmaceutical sector, investment in R\&D—and its alignment with marketing-is a major form of competition. ${ }^{18}$

The remainder of the article is organized as follows. The second section begins with the main characteristics of the retail prescription market. The third section contains a short description of the ethical tranquilizer sector in the United States in the 1950s. In the fourth section, we show the likely harm to competition caused by field-of-use restrictions in patent licensing contracts. The main conclusions are set out in the final section.

\section{Selling Drugs in the Prescription Tranquilizer Sector}

The golden age of drug discovery, or the therapeutic revolution, began around 1935 with the introduction of vitamins, hormones,

16. Boldrin and Levine, Against Intellectual Monopoly; Kremer, "Patent Buyouts”; Stiglitz, "Give Prizes not Patents"; Wright, "Economics of Invention Incentives”; Lall, "International Pharmaceutical Industry”; Steele, "Monopoly and Competition"; Steele, "Patent Restrictions"; Arrow, "Economic Welfare”; Polanyi, "Patent Reform"; Lall, "Price Competition."

17. Comanor, "Research and Competitive Product Differentiation”; Grabowski and Vernon, "Substitution Laws."

18. Slinn highlights the complementarity between patenting and marketing. Slinn, "Patents and the UK Pharmaceutical Industry." 
sulfonamides, and antibiotics and their derivatives, and it came to an end in the 1970s. ${ }^{19}$ During this period, drug development was a highly profitable activity, firms invested heavily in R\&D, and competition increased as new products with incremental advances were introduced. ${ }^{20}$ These years of the therapeutic revolution also witnessed American's growing enthusiasm for prescription pills, the rise of national health services, the expansion of the market, increasing government control over drug development, and concerns about rising health care costs. ${ }^{21}$ The exponential growth of the pharmaceutical industry from this therapeutic revolution and the expansion of the market are reflected in the fact that, by 1960, around 70 percent of all sales came from products that had not existed before 1951. ${ }^{22}$

Following World War II, the pharmaceutical sector was characterized by intense product differentiation and product competition. ${ }^{23}$ Different manufacturers could market the same chemical entity under a number of separate and distinct brand names or under its generic name. During the patent period, the original manufacturer could license other firms to sell the drug, some with their own brand name and others with the generic name. ${ }^{24}$ Thus, the same drug was often marketed under different names. This approach is known as product differentiation.

Product competition was also intense in the pharmaceutical sector. When one firm was awarded a patent, other firms attempted to modify the molecular structure of the relevant compound in order to discover drugs with limited incremental advances in therapeutic value. Such drugs might be similar to those products already on the market yet sufficiently different to win a patent. ${ }^{25}$ Pharmaceutical companies generally recognized that they were in a race with other firms to develop innovative drugs. ${ }^{26}$ It was the era of molecular modification,

19. Quirke, "Material Culture of British Pharmaceutical Laboratories”; Anderson, Making Medicines, 168.

20. Henderson, Orsenigo, and Pisano, "Pharmaceutical Industry."

21. Quirke, "From Alkaloids to Gene Therapy"; Slinn, "Development of the Pharmaceutical Industry." Price regulation began because it was thought that to do so would contribute to containing healthcare costs. Slinn, "Price Controls or Control Through Prices?”

22. Munos, "Lessons from 60 years”; Greene, "Attention to 'Details,"” 338.

23. Comanor, "Research and Competitive Product Differentiation."

24. Greene, Generic, chapter 2.

25. Comanor, "Political Economy”; Greene, Generic, 211-230.

26. It was during the interwar years when the core pharmaceutical companies began to develop research networks, making research part of their competitive strategy. Tobbell, Pills, Power and Policy. The importance of first-mover advantage was very clear in this sector and one of the reasons for early patenting: being first to market with a new product brought high rewards. David, Foray, and Steinmueller, "Research Network." 
meaning that not all drugs on the market were really innovative; rather, they were duplicate drugs under different names. Such products are called false innovations, me-too, or duplicative drugs, and are defined as drugs with chemical properties and therapeutic effects similar to those of drugs already on the market. ${ }^{27}$ They were considered innovative due to their new characteristics; for example, better taste or better metabolism. The importance of molecular modification was reflected in the fact that the bulk of spending on research by pharmaceutical companies was "to exploit and market the foreign advances or to modify the original drugs just enough to get a patentable derivative, but not to change it enough to jeopardize the original effect."28

The vast majority of "new" drugs were variations of older drugs already on the market, although they may have been important for some patients due to their therapeutic properties. ${ }^{29}$ However, the number of new chemical entities (that is, a drug or chemical without precedent among regulated and approved drug products because of its significant therapeutic advance) was comparatively small. More than 4,560 new ethical drugs were introduced in the period 19511961, of which only 360 were truly innovative drugs; that is, new chemical entities.

The me-too business was possible because the Food and Drug Administration (FDA), which had been authorized starting in 1938 to approve prescription drugs; it usually approved a drug simply if it was better than a placebo, but it was obligated to certify only its safety, not its efficacy. ${ }^{30}$ Sometimes there was not even the slightest difference between different products; nevertheless, competing companies advertised them as different compounds. The FDA was required to

27. In the economic literature, these combinations of well-known molecules are called minor innovations or incremental innovations, and new chemical entities are called radical innovations. Kessel, "Beyond Innovation,” 16-17.

28. Testimony by Frederick H. Meyers, associate professor of Pharmacology, University of California, "Administered Prices in the Drug Industry" (hereafter “Administered Prices”), 86th Cong., 1960, 2nd Session, part 18, at 10,394. Most molecular modifications yielded only me-too products. Silverman and Lee, Pills, Profits and Politics, 5.

29. A former head of research at Squibb estimated that more than half of this company's drug research was targeted at developing copycat drugs. "Administered Prices," 86th Cong., 1960, 2nd Session, part 18, at 10,380.

30. Prior to the 1962 drug amendments, Congress gave jurisdiction over drug advertising to the FTC. The FDA had limited authority and only regulated direct advertising to doctors. A more restrictive FDA policy for drug approval followed the 1962 drug amendments, when the FDA increased its demands for evidence of efficacy and safety. The new legislation gave the FDA jurisdiction to regulate prescription drug advertising and gave control over nonprescription drug advertising to the FTC. Donohue, "History of Drug Advertising." On the regulatory role of the FDA and its influence, see Carpenter, Reputation and Power; Tobbell, Allied Against Reform; Marks, "Making Risks Visible." 
give clearance only to new drugs, so new combinations of familiar drugs did not have to be re-evaluated.

Intense product rivalry due to the high levels of investment in $\mathrm{R} \& \mathrm{D}$, as new product introductions and incremental advances were introduced, forced pharmaceutical firms to engage in costly marketing campaigns in order to increase sales of a particular brand. ${ }^{31}$ New products were especially important in the pharmaceutical industry, as treatments of diseases were continually changing and new diseases were conceptualized by pharmaceutical marketing. ${ }^{32}$ Clinical research results and laboratory science were extensively used for (scientific) marketing purposes, particularly after the 1950s, and they were fundamental in shaping the drug market. The rise of scientific marketing, including medical information in promotional material for physicians, was closely related to the rapidly changing market caused by the introduction of new drugs. Marketing was also used to promote and redefine disease categories and to reshape prescription patterns, and thereby create new markets and expand existing markets for establishing drugs. As Jean Paul Gaudillière analyzed, Ciba for example, transformed a tranquilizer into an antidepressant, redefined a new form of depression to be treated with antidepressants, and focused on the idea of the preventive action of antidepressants. ${ }^{33}$ By doing so, this company was able to build a market for antidepressants to treat a great number of patients suffering from mental problems. ${ }^{34}$

This product competition created increased rivalry in the drug industry for patented drugs and made it inevitable that firms would spend huge amounts of money on marketing in order to increase

31. The introduction of new products leads to more competition and, in turn, greater competition leads to more investment in R\&D. Large R\&D expenditures and a highly organized research effort are required to ensure a reasonable probability of success.

32. The introduction of new drugs expanded the incidence of a disease, increasing the potential market for a drug through the detection of hidden (undiagnosed and untreated) patients. A new drug could alter and expand the definition of a disease category by focusing mainly on the treatment of risk via the detection and treatment of asymptomatic diseases. Another way to increase a drug's market share was to seek new indications in other established disease categories or to claim that the new drug was safer and more efficient than existing drugs. For more on how new drugs influence the definition of disease, see Greene, Prescribing by Numbers. For the construction of mental disorders, see Shorter, History of Psychiatry; Rasmussen, On Speed; Healy, Let Them Eat Prozac; Herzberg, Happy Pills in America; Tone, Age of Anxiety.

33. Gaudillière, "Marketing Loops."

34. Moon emphasized the creation of pharmaceutical markets by the drug industry, the role of the doctor in directing the hand of the market, and the introduction of new products in response to the experiences of physicians. Moon, Amphetamine Years. 
their sales. ${ }^{35}$ The introduction of numerous drugs with very similar therapeutic effects prompted companies to engage in major marketing efforts, as they could not compete on the basis of these effects. ${ }^{36}$ If they wished to survive competition in the market, firms had to advertise their products heavily through different channels, including medical journals, films, radio, television, samples, and pharmaceutical representatives. ${ }^{37}$ This strategy resulted in an increase in advertising by firms in the 1950s from approximately 10 percent to roughly 15 percent of sales to promote their innovations. ${ }^{38}$ The bulk of advertising and promotional efforts went into persuading doctors to prescribe specific brand names; by the 1960s, more than 90 percent of the pharmaceutical companies' spending on marketing was aimed at doctors (only 10 percent was toward pharmacists and hospitals). ${ }^{39}$

This high level of advertising focused on doctors explains why, after 1938, decisions regarding patients' use of prescription drugs were mainly in the hands of physicians, as they were the people prescribing the drugs. ${ }^{40}$ Moreover, druggists were limited to issuing the trademark written on the prescription. During the 1950s, forty-four U.S. states enacted antisubstitution laws to prohibit brand substitution as a result of an alliance among physicians, pharmacists, and the brand-name pharmaceutical industry. These laws constrained the use of drugs sold under their generic names. In this situation, pharmacists

35. Rivalry through nonprice competition explains the high sales, advertising, and promotional expenditures (such as detail men, samples, journal advertising, mail, and so on), the emphasis on product development, and a closer alignment of research and (scientific) marketing activities. For the interplay between clinical research and promotion and professionalization of marketing, see Gaudillière and Thoms, Development of Scientific Marketing. Smith Kline and French was one of the first companies to use scientific progress as a marketing argument. Rasmussen, "Making the First Anti-Depressant."

36. For the different marketing strategies used by Ciba to promote the hypnotic drug Doriden during the 1950s and early 1960s, see Kessel, “'Doriden von Ciba." For the professionalization of marketing activities by Shering after 1945, see Gaudillière, "From Propaganda to Scientific Marketing." For pharmaceutical marketing in Germany between 1900 and 1980, see Thoms, "Standardizing Selling."

37. Most authors date the massive rise of advertising and modern marketing to the 1950s. However, in the case of German pharmaceutical companies, Thoms dates the emergence of pharmaceutical marketing at the core of business organizations to the 1930s. Thoms, "Standardizing Selling."

38. Temin, “Technology Regulation,” 431.

39. Donohue, "History of Drug Advertising," 668. The ethical drugs firms persuaded doctors and druggists of the superiority and reliability of their brands. Advertising for prescription medications became restricted to physicians only after Congress passed the Food and Drug Act of 1906. Liebenau, Medical Science and Medical Industry.

40. For more on physicians' autonomy, authority, and challenges in prescribing drugs, see Greene and Siegel Watkins, Prescribed. 
were legally bound by their state laws to fill prescriptions as written by doctors. ${ }^{41}$ However, purchase decisions of prescription drugs did not lie solely in the hands of physicians. ${ }^{42}$ In the 1940 s, wide prescription drug abuse started "adding up to an astonishing 15 million Americans by the late 1960s. The FDA estimated that half of all amphetamine pills in the 1960s were dispensed without the benefit of prescriptions." 43 Moreover, David Herzberg indicates that consumers with problems of addiction pressured their doctors to change their types of drugs, increasing the number of refills or increasing the quantity written on the prescriptions. ${ }^{44}$

These antisubstitution laws also encouraged firms to focus on marketing and promotion. The proliferation of brands meant that advertising became a significantly important strategy to increase sales. ${ }^{45}$ Patent-holders used their patent period to promote their product's brand name to physicians and tried to persuade them to use it for reasons of quality, rather than price. ${ }^{46}$ Leading pharmaceutical companies justified their enormous expenditures on promotion and advertising by arguing that a trademark gave a guarantee of purity and strength, as well as the quality of a well-known firm with a recognized reputation. The industry argued that drugs with the same generic name but different proprietary names could differ in their therapeutic effects. These are the reasons the industry cited to oppose Senator Kefauver's proposal in S. 1552 to encourage physicians to prescribe drugs by their generic name. Generic prescribing would be unsafe because of the

41. The last of these antisubstitution laws was repealed in 1984; most had been repealed in the mid- to late 1970s. Greene, Generic, chapter 8.

42. For the pressure applied to physicians by patients to prescribe new drugs, see Mintz, Therapeutic Nightmare. For the active role of women in demanding prescriptions for minor tranquilizers, see Smith, Social History of the Minor Tranquilizers. For the contraceptive pill in Germany starting in the late 1960s, see Thoms, “Contraceptive Pill.” For Spain, see Ignaciuk, Ortiz-Gómez, and Rodriguez-Ocaña, "Doctors, Women and the Circulation of Knowledge."

43. Herzberg, "Busted for Blockbusters," 214.

44. Ibid.

45. Consumers could self-medicate because all drugs were promoted directly to consumers until 1938, when the only drugs for which prescriptions were needed were some narcotics and cocaine. Congress passed the Federal Food, Drug, and Cosmetic Act in 1938, which restricted the consumers' role and reduced that of pharmacists in the selection of drugs, making the demand for prescription drugs more inelastic than it would have been without this FDA regulation. As a result, after 1938, brand-name drug firms greatly increased their advertising and promotion to physicians. See Temin, "Technology, Regulation”; Statman and Tyebjee, "Strategic Responses"; Temin, "Origin of Compulsory," 97-98.

46. Bond and Lean demonstrated the promotion of the brand name to foster physician loyalty during the patent period. Bond and Lean, Economic Report on Sales. The persistence of loyalty to a branded drug maintained the position of a patented drug even after the patent expired. Statman, "Effect of Patent Expiration"; Statman and Tyebjee, "Trademarks, Patents, and Innovation." 
existence of substandard drugs sold under generic names, with substitution being defined as a health hazard. It was argued that brandname products inspired confidence among physicians, and this then explained the high percentage of drugs prescribed by brand name. ${ }^{47}$ In addition, a risk-averse physician would not prescribe a drug by its generic name until its efficacy was proved. The private doctor would be much more inclined to trust the trademark on the assumption that the relevant company would be safe. They, therefore, placed their trust in firms' sizes and reputations, since they had no way of knowing the quality of all the manufacturers. ${ }^{48}$ Moreover, doctors were not sensitive to price differences, and even tended to be unaware of prices. Habit, therefore, played a major role in physicians' prescription practices. ${ }^{49}$ The result was that doctors prescribed only a few of the many available brand-name drugs-that is, the most heavily advertised drugs, which were those of the big companiesand this meant that smaller firms never developed the capacity to finance selling campaigns.

For a small company, it was very difficult to finance a selling campaign. ${ }^{50}$ Promotional expenditures were far greater than those for R\&D. For example, the amount spent on R\&D in 1958 by the twenty largest companies with the highest annual sales of drugs represented 6.4 percent of their total pharmaceutical sales ( $\$ 2.3$ billion). ${ }^{51}$ This proportion was not particularly high, given that the companies' selling expenses were 24 percent (one-third of the total cost of production ${ }^{52}$ ) and net profits were 13.1 percent. ${ }^{53}$ These data (see table 1) show that selling costs were almost four times that of research expenses.

47. However, sales promotion for drugs sold mainly to hospitals was very low. Leffler, "Persuasion or Information?," 53-54.

48. By the early 1960s, the generic name was not a useful tool for establishing the interchangeability among drug products bearing the same generic drug name. Greene, Generic, 48.

49. Kendall, Ng, and Schoner, "Consumer Responses”; Temin, “Taking Your Medicine," 102-106.

50. It cost about $\$ 750$ million per year in 1958. Silverman, Drugging of the Americas, 121; Clarkson, "Use of Pharmaceutical Profitability Measures."

51. A small number of companies produced a high percentage of innovations. Achilladelis and Antonakis, "Dynamics of Technological Innovation." The high cost of R\&D excluded small firms from using it on a sufficiently large scale to expect success and explains the dominance of large companies in drug research. Schwartzman, Innovation in the Pharmaceutical Industry, chapter 5.

52. There were some firms with higher selling and distribution costs, such as Upjohn with a percentage of 28.8, or Schering with a percentage equal to 32.7 of their sales revenue. Testimony by Mr. Brown, president of Schering; Mr. Upjohn, president of Upjohn Company; and Senator Kefauver, "Administered Prices," 86th Cong., 1960, 1st Session, part 14, 1960.

53. Testimony by Senator Kefauver, “Administered Prices,” 86th Cong., 1960, 2nd Session, part 19, 1960. 
Table 1. Breakdown of sales dollar, 20 major drug companies, 1958 (in percent of sales*)

\begin{tabular}{lccccc}
\hline & $\begin{array}{c}\text { 20 Drug } \\
\text { Companies }\end{array}$ & $\begin{array}{c}\text { Smith Kline \& } \\
\text { French }\end{array}$ & $\begin{array}{c}\text { Carter } \\
\text { Products }\end{array}$ & $\begin{array}{c}\text { American } \\
\text { Home Products }\end{array}$ & Ciba \\
\hline Net profit & 13.1 & 17.2 & 20.4 & 14.7 & 12.7 \\
Taxes & 13 & 20 & 23.4 & 15.9 & 12.9 \\
Selling expenses & 24 & 19.5 & 27.8 & 24 & 33.9 \\
General \& & 11.2 & 10.9 & 6.5 & 14.9 & 7.4 \\
$\quad \begin{array}{l}\text { administrative } \\
\quad \text { expenses }\end{array}$ & & & & & \\
R\&D expenses & 6.4 & 8.9 & 2.7 & 3.2 & $13.9 * * *$ \\
Cost of goods ** & 32.3 & 23.5 & 19.2 & 27.3 & 19.2 \\
\hline
\end{tabular}

Source: "Administered Prices," 86th Cong., 1960, 2nd session, part 16, at 9,176-9,177.

Note: ${ }^{*}=$ includes royalties and other income. ${ }^{* *}=$ includes labor costs, material costs, bottling, finishing into tablets or capsules, and depreciation on plant. ${ }^{* * *} 3$ percent of the 13.9 is for the patents to the Swiss company, with U.S. research being about 10 percent.

In sum, big pharmaceutical companies integrated marketing techniques with R\&D activities to increase their market shares and to withstand competition from drugs that were chemically different but offered the same therapies. This explains the high rate of product obsolescence and rapidly growing markets, which stimulated competition and provided an impetus to innovate. ${ }^{54}$ In turn, the profitability of investments in drug R\&D and marketing led to more innovation and more drugs. ${ }^{55}$

In the tranquilizer sector, there were many medications but not many significant improvements, although a small reduction in the incidence of side effects could be demonstrated with the new drugs. For example, although there were several types of tranquilizers, medical opinion inclined to the view that the later modifications of the original phenothiazines were therapeutically similar to the first ones that were released. The advances made following the discovery of chlorpromazine, the first of the antipsychotics, were small and incremental. There were drugs with similar properties patented and marketed as competing products that were as effective but had fewer or different side effects. ${ }^{56}$

54. Mahoney, Merchants of Life; Marks, Progress of Experiment.

55. In 1958, among the 500 largest industrial corporations in terms of total sales, the next pharmaceutical companies were among the 150 highest profit corporations in terms of profits on investment (as reported by Fortune magazine, volume 60 (2), August 1959: American Home Products, Smith Kline and French, Schering, Parke Davis, Upjohn, Pfizer, Merck, Abbott, Bristol-Myers, and Eli Lilly. Carter Products, if it had sales sufficiently large to put it among the 500 largest, would rank the leading company). "Administered Prices," 86th Cong., 1960, 2nd Session, part 16 , at 8,945 .

56. Testimony by Dr. Lehmann, “Administered Prices,” 86th Cong., 1960, 2nd Session, part 16, at 9,029; Steele, "Monopoly and Competition,” 156. 
The importance of promotional expenses for a particular drug is well illustrated in this sector. Tranquilizer advertising was the major component of medical advertising, as indicated by the executive director of the National Committee Against Mental Illness. Miltown and Equanil, for example, were heavily advertised as a condition of Wyeth's license with Carter: Wyeth would spend at least 20 percent of total meprobamate sales revenue on its promotion. Despite its high price, Miltown was the most widely used. It was the first psychotropic blockbuster and the fastest-selling drug in U.S. history. ${ }^{57}$

The cost of Miltown per tablet for a 1,000-tablet production run is shown in table 2. Advertising, promotion, and clinical samples cost one cent per tablet-Carter's total advertising and promotion cost for Miltown was $\$ 9.20$ per year per doctor in 1959-as compared to seven-tenths of one cent, which was the manufacturing cost per tablet, or about one-and-a-half times more. Research and royalties were four-tenths of a cent per tablet, which was less than half the expenditure for advertising and promotion. The net profit for the manufacture and sale of Miltown was 23 percent per tablet.

Although there was little overuse of potent tranquilizers-patients did not like to take them owing to their unpleasant side effects-the less potent ones were overused to a tremendous degree. The minor tranquilizers were everywhere in the popular media, thanks to intense marketing and the widespread view that anxiety was not so much a sign of mental illness as a symbol of success. ${ }^{58}$ The consumerist culture also explains why these drugs were initially quite popular. ${ }^{59}$

57. Tone, Age of Anxiety. Meprobamate was popularized through a major advertising campaign. Herzberg, Happy Pills in America, 38-39. By 1957 more than 36 million prescriptions had been filled for meprobamate in the United States alone. Tone, “Tranquilizers on Trial," 157. Carter had been involved in aggressive advertisings since the 1930s. Herzberg, Happy Pills in America, 21.

58. In cases of milder emotional disturbances, a great number of patients (from 20 percent to 40 percent) would improve with any kind of a pill because of the so-called placebo effect. This also holds true for depression. Testimony by Dr. Lehmann, “Administered Prices," 86th Cong., 1960, 2nd Session, part 16, at 9,028 and 9,072 .

59. The minor tranquilizers created a new market because the use of barbiturates did not decline when the former arrived on the market. The explosive rise of minor tranquilizers was carried out by doctors prescribing nonpsychiatrics. Rasmussen, On Speed. For Miltown's success as a consumer commodity and the creation of America's tranquilizer culture, see Tone, Age of Anxiety. For the idea that minor tranquilizers created a psychotropic culture from the mid-1950s, see Metzl, Prozac on the Couch. For the increase in the prescribing of minor tranquilizers being caused by social reasons rather than medical ones, see Smith, Social History of the Minor Tranquilizers. 
Table 2. Miltown costs and profit per tablet by Carter, March 31, 1959 (cents per tablet)

\begin{tabular}{lll}
\hline Carter receives from wholesaler & 5.1 & \\
\hline Manufacturing costs & 0.7 & $17.9 \%$ \\
Selling expense and administration* & 0.4 & $10.3 \%$ \\
Advertising, promotion and clinical samples* & 1.0 & $25.6 \%$ \\
Research and royalties* & 0.4 & $10.3 \%$ \\
Income taxes* & 1.4 & $35.90 \%$ \\
Total cost per tablet & 3.9 & $100 \%$ \\
Net profit & 1.2 & \\
\hline
\end{tabular}

Source: "Administered Prices," 86th Cong., 1960, 2nd session, part 16, at 9,161.

Notes: ${ }^{*}=$ these expense items are average for Carter's ethical drug business.

The abuse of minor tranquilizers-especially of meprobamate-was remarkable, although there was little evidence that the drug was qualitatively different in its clinical effects from a number of other hypnotics, including barbiturates. ${ }^{60}$ The danger with this practice was the problem of addiction; for example, large doses of meprobamate (Miltown, Equanil, and various other trade names) over a long period of time could cause addiction.

The development, introduction, and marketing of potent and dangerous drugs increased concerns regarding the regulation of the industry as a means to protect consumers. At this time, there was major government and public concerns regarding drug safety regulation, the abundance of me-too drugs, and industry marketing practices. Kefauver's hearings were initially predicated on concerns about monopolistic pricing, but as the hearings continued attention focused increasingly on pharmaceutical marketing, consumer safety, and drug efficacy. Specifically, Kefauver's greatest achievement was the Kefauver-Harris Drug Act of 1962 (also called the drug amendments) because it directly related to the drug industry and health issues. This was the first major change of the preceding law: the Federal Food, Drug, and Cosmetic Act of 1938. This act required manufacturers to show that a drug was safe, and drugs had to receive the FDA's approval before they could be marketed. The Drug Act of 1962 was one of the most significant consumer safety laws of the twentieth century: to receive approval by the FDA, a new

60. There was no evidence that meprobamate was different from a placebo in treating anxiety in psychiatric outpatients, although it was better than a placebo in hospitalized neurotic and psychotic patients. Laties and Weiss, "Critical Review of the Efficacy of Meprobamate.” For example, Compazine-a drug effective for severe disturbances-was also sold for milder mental and emotional disturbances, even though it had not been shown to be as effective against mild disturbances, as reported in a study by Lasagna, a doctor at Johns Hopkins. "Administered Prices,” 86th Cong., 1960, part 17 , at 9,507 . 
drug's efficacy and safety had to be demonstrated prior to marketing. ${ }^{61}$ All drugs approved between 1938 and 1962 were reviewed under the new law, and those which were found to be ineffective were removed from the market. Thus, the drug hearings triggered major progress for consumer safety legislation and expanded the FDA's authority over the testing, manufacturing, and marketing of new drugs. ${ }^{62}$ Furthermore, Kefauver's investigation encouraged crucial debates on contemporary decisions in U.S. health policy and practice. ${ }^{63}$

As a result of the hearings held by the Subcommittee on Antitrust and Monopoly, Kefauver introduced a bill (S. 1552) to the subcommittee in 1961 designed to increase competition, to enhance the use of generic names, and to reform the patent system. It introduced compulsory licensing and the granting of patents only in relation to those drugs that were true innovations (and not me-too drugs). The bill met with strong resistance from two Democratic senators (Everett Dirksen and Roman Hruska), the American Medical Association, and the Pharmaceutical Manufacturers' Association (PMA), the industry's trade association. The PMA included only 140 firms from among more than 1,300 mainly medium- and large-size firms that produced almost 95 percent of all sales of prescription drug in 1960. President John Kennedy and the White House staff were also reluctant to support the bill. Two of the arguments advanced by the PMA to oppose the charges made by Kefauver were: (1) the superiority of the U.S. free enterprise model, and (2) the benefits of the competitive system as the best asset in the struggle against Communism. ${ }^{64}$ Finally, however, Kennedy signed the bill into law in October 1962 (the Kefauver-Harris Drug Act), but the patent provisions were rejected. ${ }^{65}$ The Kefauver-Harris Drug Act was the

61. This law was passed following the thalidomide disaster (a drug introduced in several foreign countries but not the United States), in which thousands of children were born with birth defects. For a review of the thalidomide disaster and regulatory reform, see Carpenter, Reputation and Power, chapter 4.

62. As Greene and Podolsky wrote: "Senator Kefauver's investigation of 'Administered Prices in the Pharmaceutical Industry: Pharmaceutical Promotion and Physician Education in Postwar America' in many ways served as the end of the unblemished era of the wonder drug." Greene and Podolsky, "Keeping Modern in Medicine," 357.

63. Scroop, "Faded Passion?”; Tobbell, "Who’s Winning the Human Race?,” 431.

64. The efficacy requirement included in the drug amendments favored the economic position of PMA members' companies because it eliminated many fringe manufacturers from the marketplace. For more on the political strategy to undermine regulatory reform and the alliances the drug industry built among academics, physicians, and the American Medical Association, see Tobbell, “'Who's Winning the Human Race?",

65. The provisions included reducing the then-existing seventeen-year patent terms, adding compulsory licensing after three years of patent protection, and giving patents combinations and modifications of existing products only if they were therapeutically superior to the original products. 
first legislation to regulate the efficacy and safety of new drug products and reflected changes in the U.S. economy toward a politics of consumption. Regulation of pharmaceuticals became a national problem in the United States following Kefauver's hearings. ${ }^{66}$

\section{The Rise of the Tranquilizer Sector in the United States}

In the 1950s mental illness was a major health issue in the United States, with at least 25 percent of visits to doctors due to mental health problems, ${ }^{67}$ and filling more than half the hospital beds in the country. Around 10 percent of Americans suffered from some form of mental illness, which cost the nation $\$ 3$ billion a year. ${ }^{68}$ In 1958 sales of tranquilizers at the manufacturers' level were estimated at nearly \$200 million a year (total annual sales of drugs for the United States were roughly $\$ 1.8$ billion). ${ }^{69}$

The introduction of effective drug therapy and its extensive use in the treatment of the mentally ill began in the 1950s. It was widely used to treat psychosis, depression, anxiety, and mania. ${ }^{70}$ This changed the course of psychiatry, as practitioners began to consider both psychotherapy and psychopharmacology as regular treatments. ${ }^{71}$ Interestingly, the discovery of these drugs was accidental and began with the

66. Greene and Podolski, "Reform, Regulation, and Pharmaceuticals"; Steele "Fortunes of Economic Reform Legislation"; Carpenter, Reputation and Power; Greene and Watkins, Prescribed, 75-77; Tobbell, "Pharmaceutical Politics," 123-139.

67. Rasmussen, On Speed, 114.

68. Testimony by Mike Gorman, "Administered Prices,” 86th Cong., 1960, 2nd session, part 16, at 8,985 .

69. Silverman and Lee, Pills, Profits and Politics, 327.

70. There are several studies that conclude that the use of psychopharmacology to treat mental illness became formalized in the 1950s and led to the deinstitutionalization movement that gathered momentum from the 1960s onward. The number of patients in mental hospitals began to decline, reflecting the introduction of psychopharmacology in the treatment of mental illness. The number of institutionalized mentally ill people in the United States dropped from a peak of 560,000 (in state and county mental hospitals, which accounted for almost half of all mental patients) to about 339,000 in 1970 (accounting for less than 10 percent of all mental patients). Schwartzman, Innovation in the Pharmaceutical Industry, 21; Gronfein, Psychotropic Drugs, 437; Bachrach, State of the State Mental Hospital, 93; Tone, Age of Anxiety, 13; Herzberg, Happy Pills in America, 18. However, on this subject there is a debate about whether the introduction of psychopharmacology or the move to deinstitutionalize mental healthcare came first. For the argument that the asylum population began to fall much earlier than the introduction of chlorpromazine, see Healy, Creation of Psychopharmacology. For the idea that the introduction of psychotropic drugs was not statistically significant to explain deinstitutionalization trends, see Mechanic and Rochefort, "Deinstitutionalization."

71. Ban, "Fifty Years Chlorpromazine." 
synthesis of a number of phenothiazine antihistamines in the 1940s, which manufacturers then discovered were effective sedatives. ${ }^{72}$

The arrival of new drugs capable of altering moods and mental illness challenged ideas about psychiatry and mental disorders, which were now attributed to brain chemistry. Anxiety was the common term used to refer to mental problems treated on an outpatient basis. The new psychiatry paradigm led to a conception of anxiety as a general psychic consequence of the demands and pace of conditions of modern life. Because anxiety was common and related to many ills, the introduction of drugs to treat problems of generalized stress and to enhance well-being created a mass market, and doctors became increasingly oriented toward prescribing pharmaceuticals. ${ }^{73}$ This new market included those populations who began to think that mental distress could be treatable by drugs, having been persuaded by public relations and marketing efforts to grab the consumers' attention. ${ }^{74}$ The popularity of these drugs explains psychiatry's pharmacological revolution, which began in the 1950s. In many publications from those years, one can read about the value of minor tranquilizers for a great number of life problems, including tension, nerves, irritability, menstrual stress, psychosomatic symptoms, insomnia, menopause, juvenile delinquency, family and marital difficulties, and problems at work.

At the end of the 1950s, there were three main classes of patented tranquilizers sold under a generic name or a brand name (table 3): phenothiazine derivatives (the most common of which were Compazine and Thorazine); alkaloids of Rauwolfia serpentina (the most important was reserpine); and finally, a miscellaneous group, principal among which was meprobamate. All of these drugs, termed ethical drugs, were sold by prescription. The first two groups included potent tranquilizers-or major tranquilizers or antipsychotics-that were largely used for the treatment of those hospitalized and other seriously ill mental patients. These proved to be extremely effective in combating major mental diseases. The other classes of tranquilizers, which received the most publicity, were usually simple sedatives,

72. Barbiturates and opiates were some of the chemical treatments used to treat anxiety before the arrival of minor tranquilizers. Tone, Age of Anxiety.

73. Sales of tranquilizers at the manufacturers' level were estimated at nearly $\$ 200$ million a year. Herzberg, Happy Pills in America, Appendix B, 209.

74. Smith, Social History of the Minor Tranquilizers, 67, points out the following examples: “'Wonder Drug' (Time, 1954); 'Happiness Pills' (Newsweek, 1956); 'Aspirin for the Soul' (Changing Times, 1956); 'Mental Laxatives' (Nation, 1956); 'Don't-Give-A-Damn Pills' (Time, 1956); 'Peace of Mind Drugs' (Mental Health, 1957), and even 'Turkish Bath in a Tablet' (Reader's Digest, 1962).” The literature became more critical over the years. Smith, Social History of the Minor Tranquilizers, 128. 
Table 3. Major marketers of mental drugs, 1958

\begin{tabular}{|c|c|c|c|c|c|}
\hline Products & $\begin{array}{c}\text { Date } \\
\text { introduced }\end{array}$ & $\begin{array}{c}\text { Major } \\
\text { marketers }\end{array}$ & $\begin{array}{l}\text { Trade } \\
\text { names }\end{array}$ & $\begin{array}{l}\text { Estimated } \\
\text { current } \\
\text { sales rate } \\
\text { (millions } \\
\text { dollar) }\end{array}$ & $\begin{array}{c}\text { Price to } \\
\text { druggist } \\
\text { (50 tablets) }\end{array}$ \\
\hline \multicolumn{6}{|c|}{ Phenothiazine derivatives (potent tranquilizers) } \\
\hline Chlorpromazine & 1954 & SKF & Thorazine & 25 & 3.03 \\
\hline Prochlorperazine & 1956 & SKF & Compazine & 20 & 3.03 \\
\hline Promazine & 1957 & $\begin{array}{l}\text { Wyeth Division } \\
\text { of AHP }\end{array}$ & Sparine* & 15 & 3.00 \\
\hline Perphenazine & & Schering & Trilafon & 1 & \\
\hline Pecazine & 1957 & Warner-Lambert & Pacatal & 6 & \\
\hline Vesprin & & & & $<1$ & \\
\hline \multicolumn{6}{|c|}{ Substituted propanedoils (muscle relaxants, mild tranquilizers) } \\
\hline \multirow[t]{2}{*}{ Meprobamate } & 1955 & $\begin{array}{l}\text { Wallace Division } \\
\text { of Carter } \\
\text { Products, Inc. }\end{array}$ & Miltown & 15 & 3.25 \\
\hline & & $\begin{array}{l}\text { Wyeth Division } \\
\text { of AHP }\end{array}$ & Equanil & $35-40$ & 3.25 \\
\hline Phenaglycodol & & Eli Lilly & Ultran & $3-4$ & \\
\hline \multicolumn{6}{|c|}{ Diphenylmethane derivatives (basically antihistamine products, mild tranquilizers) } \\
\hline Hydroxycine & 1956 & Pfizer & Atarax & 9 & \\
\hline $\begin{array}{l}\text { Benzilate } \\
\text { hydrochloride }\end{array}$ & 1957 & Merck & Suavitil & $<1$ & \\
\hline Azacycolonol & 1955 & Vick & Frenquel & $<1$ & \\
\hline \multicolumn{6}{|c|}{ Rauwolfia alkaloids (potent tranquilizers) } \\
\hline Reserpine & 1954 & Ciba & Serpasil & 15 & 2.25 \\
\hline & & Lilly & Sandril & & 1.92 \\
\hline & & Merck & Roxanoid & & 1.91 \\
\hline & & Parke, David & Serfin & & 1.92 \\
\hline & & Squibb & Rau Sed & & 1.91 \\
\hline & & Upjohn & Reserpoid & & 1.92 \\
\hline & & $\begin{array}{l}\text { American } \\
\text { Quinine }\end{array}$ & $\begin{array}{r}\text { Generic } \\
\text { name }\end{array}$ & & 1.17 \\
\hline & & Many sellers & $\begin{array}{r}\text { Generic } \\
\text { name }\end{array}$ & & \\
\hline
\end{tabular}

Source: "Administered Prices," 86th Cong., 1960, 2nd session, part 16, at 8,887.

Note: * Sparine is half as potent as Thorazine, which is less potent than Vesprin. Compazine and Trilafon are more potent than Thorazine: the more potent the phenothiazine derivatives, the fewer side effects produced. Rauwolfia derivatives are safe compounds; serious side effects have been rare.

and their effects were mainly of a symptomatic nature (that is, mild tranquilizers). They were advertised for states of anxiety or tension and were suitable for treating the nonpsychotic patient. ${ }^{75}$

75. The use of minor tranquilizers increased dramatically through the early 1970s, and they maintained their overall position among the nation's most popular medicines. Thus, it is estimated that well more than one hundred million prescriptions were filled for minor tranquilizers yearly in the mid-1970s. Herzberg, Happy Pills in America, 39. For a discussion of the impact of minor tranquilizers on society and medicine itself, see Smith, Social History of the Minor Tranquilizers. 
In 1959 the most significant firm selling phenothiazine derivatives in the United States was the American company Smith Kline \& French (SKF), which was primarily a producer of ethical drug specialties. ${ }^{76}$ During the late 1940s, SKF was interested in researching a compound that might potentiate other drugs, especially sedatives. In 1952 the French company Rhône-Poulenc discovered a new allergy drug it called chlorpromazine, which slowed down bodily processes. The development of this drug came from an interest in the 1940s in antihistamines, as they were effective sedatives. ${ }^{77}$ In 1952 SKF obtained an exclusive license from Rhône-Poulenc to use, sell, and distribute the compound chlorpromazine in specialty form only. Rhône-Poulenc, which had applied in 1951, obtained the U.S. patent rights on July 14, 1953. ${ }^{78}$ Thorazine was the trade name chosen by SKF for chlorpromazine; the product went on sale in $1954 .{ }^{79}$ The introduction of chlorpromazine was a major milestone in the treatment of psychotic patients, ${ }^{80}$ and Thorazine became the first widely available antipsychotic medication. In 1952 SKF also obtained a license from the French company to sell prochlorperazine under the trademark Compazinea phenothiazine compound similar to chlorpromazine but much more potent. The patent was issued to Rhône-Poulenc in September 1959. SKF was the only domestic supply source for Thorazine and Compazine, and it had estimated sales of \$24 million of Thorazine and $\$ 20$ million of Compazine, representing around 20 percent of the tranquilizer market in 1958 and around 60 percent of phenothiazine derivatives (see table 3). ${ }^{81} \mathrm{SKF}$ signed more patent licensing contracts with Rhône-Poulenc. In 1956 SKF entered into an agreement with the French company to use Thorazine in combination with other products. That new product was named Thoradex.

Rhône-Poulenc also signed patent licensing contracts with other companies, such as with American Home Products Corp. (hereafter AHP),

76. Seventy percent of the sales of this company came from items that affect the central nervous system: tranquilizers such as Thorazine (30 percent), Compazine , and Thoradex, and stimulants like Benzedrine, Dexedrine, and Dexamyl. "The remaining 30 percent came from hormones and sulfur drugs, plus specialties to treat nasal, skin, allergy, and blood pressure disorders." "Administered Prices," 86th Cong., 1960, 2nd Session, part 17, at 9,481.

77. Swazey, Chlorpromazine in Psychiatry.

78. SKF obtained an exclusive license before the patent was obtained but after Rhône-Poulenc had applied for the license in 1951. The reason for offering a licensing agreement to SKF was that Rhône-Poulenc lacked the means to market chlorpromazine in the United States. Rasmussen, On Speed, 144.

79. By 1956 more than two million patients had been prescribed chlorpromazine. Harcourt, "Reducing Mass Incarceration," 65.

80. The antidepressant era began after the discovery of chlorpromazine. Healy, Antidepressant Era.

81. “Administered Prices,” 86th Cong., 1960, 2nd session, part 16, at 8,912. 
which received an exclusive license in 1957 to sell promazine (a molecular modification of the phenothiazine nucleus). Through its Wyeth Laboratories Division, AHP offered promazine under the brand name Sparine; it was a potent tranquilizer for patients seriously agitated with delirium tremens.

In 1952 reserpine, one of the first antidepressants introduced commercially in the United States, was isolated in Switzerland by Ciba from the dried root of Rauwolfia serpentine. This root had been used medicinally in Europe for more than three hundred years for the treatment of anxiety states, but it was in 1933 that a group of Indian researchers reported its value as a hypotensive agent. Ciba Pharmaceutical Company (a wholly owned subsidiary of Ciba) held the patent starting in 1956, and it sold reserpine under the trade name Serpasil. Several firms also sold reserpine, as we explain in the next section.

Meprobamate was the first minor tranquilizer and the most sold in 1958 (see table 3). ${ }^{82}$ Dr. Frank Berger accidentally discovered mephenesin, a muscular relaxant, in England; eleven years later, he and his colleague, Dr. Bernard Ludwig, discovered a molecular modification of mephenesin-meprobamate-as a tranquilizer. They filed an application in 1950, and the patent rights to meprobamate were assigned in 1955 to Carter Products Inc., which sold the drug in finished form under the trademark Miltown through its ethical drug division, Wallace Laboratories. Carter licensed one other firm, AHP, through its Wyeth Division, to sell finished meprobamate in the United States under the trademark Equanil. ${ }^{83}$

\section{Patents and Price Competition in the Tranquilizer Sector}

In the tranquilizer sector, all drugs were patented. In principle, only the owner of a patent-thus, a monopolist—could manufacture and sell the relevant product; this is, the patented drug. However, patent licensing agreements were used in the pharmaceutical industry. Licensing to other firms meant that more than one firm could produce and sell the product. One common practice, as noted earlier, was to license only to big firms, with smaller firms being excluded from licensing contracts. Usually, the patent-holder decided not to license

82. For the history of the best-selling psychotropic drug in American history, see Tone, "Tranquilizers on Trial." For the history of Miltown, in particular, see Tone, "Making of Miltown," 27.

83. Wyeth paid Carter $\$ 1.9$ million in royalties in 1957. Carter had neither connections to physicians nor the money necessary to hire salesmen to create them. However, AHP had a large force of detail men. 
small firms so as to exclude them from competition. This was because of their lower costs: there were no economies of scale in production and small firms did not commit significant resources to R\&D and marketing, which were two barriers to entry in the prescription retail market. With lower costs, if smaller firms had access to bulk powders, they could sell licensed drugs cheaper than the licensor. This situation was only possible if the licensor decided to give a license to a small firm, or in those few cases in which the bulk drugs were available to all makers of preparations containing them. This happened when licensing contracts did not include field-of-use restrictions. ${ }^{84}$

However, another frequent practice was for patent licensing contracts to include a restrictive clause, specifically a field-of-use restriction; that is, a provision stipulating that the firm would be granted a license only to make and sell in final packaged form, not in bulk form. Therefore, if the patent licensing contract included this restriction, small firms were not allowed to buy ingredients in bulk and could not manufacture tablets but had to purchase the drugs exclusively in finished packaged form from the licensees and the patent holder, and thus at a higher price. As a result, in most cases, the only producers were those big firms that held patents on the drug ingredients and the licensees.

In this section, we examine whether field-of-use restrictions in patent licensing contracts truly prevented competition in the tranquilizer sector. This restrictive clause was included in all patent licensing contracts regarding the main new tranquilizers discovered in the 1950s, except for reserpine. Thus, for example, there were field-of-use restrictions prohibiting licensees to sell in bulk form in the licensing contracts that Rhône-Poulenc issued to SKF to manufacture and sell the drug chlorpromazine under the trademark Thorazine and the drug prochlorperazine; in the contract that Rhône-Poulenc signed with Wyeth, a subsidiary of AHP, to produce Phenergan and Sparine; and in the contract that Carter Products signed with Wyeth to sell meprobamate under the trademark Equanil.

We studied whether field-of-use restrictions in patent licensing contracts truly prevented competition in two different markets in which

84. Steele, "Monopoly and Competition." Patent interferences also frequently took place between big companies. When there was patent interference, the final result was very likely to be unpatentability. Big companies that researched along similar lines often pursued a strategy that allowed a patent applicant to obtain the patent; thus, they settled claims privately. All but one firm would withdraw from the interference and obtain licensing privileges through a cross-licensing arrangement, thereby avoiding patent testing and careful scrutiny of a patent application. Cross-licensing was a system whereby the product could be marketed while the battle for the patent went on, and the parties ensured the continued right to market the new compounds. 
ethical tranquilizers could be sold: the retail market (which included chain drug stores, mass merchandizers, independent pharmacies, supermarket pharmacies, and mail order pharmacies) and the institutional market (private nonprofit hospitals, state and local governmental hospitals, clinics, dispensaries, and federal agencies). In the former, as noted earlier, the people who usually decided which drugs to prescribe were doctors, and doctors tended not to care about the prices of the drugs they prescribed.

However, the institutional market was price-sensitive. In this submarket, there was no longer a captive aspect to the market, and the manufacturer had to compete on a generic basis. Thus, in the case of hospitals, hospital pharmacists were encouraged to prescribe those products listed on the hospital's formulary, and hospital physicians agreed that prescriptions written under a brand name should be interpreted as if they were generic prescriptions, unless the physician indicated otherwise. ${ }^{85}$ The idea was not only to reduce costs but also to avoid duplication in a pharmacist's orders and duplication of drug names. A hospital formulary committee and the chief pharmacist would decide on the drugs required, and quantity purchases were made on a best-bid basis. ${ }^{86}$ Hence, in contrast to the retail submarket, in which physicians and pharmacists did not have any incentive to prescribe the cheapest drug, in the institutional submarket there was a motivation to seek price cuts. ${ }^{87}$

\section{Price Competition in the Retail Market}

A field-of-use restriction in a patent licensing agreement could theoretically have been a solution to erode price competition and to increase a company's market share in the pharmaceutical market in which product competition was intense. In order to understand the relationship between restrictive licensing clauses and price competition in the retail market, we distinguished three different possible situations, dependent on the number of firms producing finished drugs

85. Memorandum 18 of the National Pharmaceutical Council, 1957, "Administered Prices," 86th Cong., 1960, 2nd Session, part. 21, at 11,835-11,836. The formulary committee consisted of representatives of the several departments of the medical staff as well as the apothecary-in-chief. Ibid, at 11,573.

86. The hospital formulary was necessary to guarantee the quality of the drugs dispensed, as there were clinically significant differences between pharmaceutical products with the same generic name. The National Pharmaceutical Council was against the hospital formulary system because the formularies constituted substitution. Greene, Generic.

87. In 1970, retail pharmacies accounted for 74.5 percent of manufacturers' domestic sales, hospitals accounted for 14.4 percent, and government agencies for the rest. Schwartzman, Innovation in the Pharmaceutical Industry, 25. 
from bulk powder active ingredients: those in which there was only one producer; those in which there were a few big firms producing the drug; and those with several manufacturers, both large and small. The distinction between these three scenarios is important in order to understand the different pricing policies of the large drug firms in the tranquilizer sector.

The first scenario is one in which only one company produced the drug; this happened with phenothiazine derivatives. In this case, Rhône-Poulenc, the owner of the patent, was a foreign company that did not operate in the United States, so it granted an exclusive license to SFK to manufacture a drug sold under its own brand name. The licensing contract included a field-of-use restriction that specified that SFK could not sell the drug in bulk form to other competitors; only it had access to the production process in the United States. We find this first situation in the contracts that Rhône-Poulenc signed with SKF to produce chlorpromazine and prochlorperazine under the trade names Thorazine and Compazine. Smith Kline and French established a price— $\$ 3.09$-for wholesale druggists (50-mg Thorazine tablet in quantities of five hundred tablets), plus 15 percent margin to retail druggists (that is, $\$ 3.64$, which was the price retail druggists paid for it). This price remained the same from 1954 to 1969. This situation was also found with the products Phenergan and Sparine, sold only by Wyeth in the United States at a price to retail druggists of \$3 in 1958 (for fifty tablets). It is obvious that no price competition existed in this first scenario, in which there was only one firm producing and selling the patented drug in the U.S. market.

We found in the second scenario that there were only a few big firms with access to the drug in bulk form. This was the case with the tranquilizer meprobamate. As noted in the previous section, only two firms manufactured this patented drug: Carter, the patent holder, and Wyeth, the licensee. The licensing contract included a restriction indicating that Wyeth would make no sales of bulk powder to any other companies, although it had access to the production process; Wyeth tableted and bottled the bulk powder sold to them by Carter. In this case, a lack of price competition was encountered in the retail prescription market, because the licensor and its licensee pursued the strategy of offering the same price for the same drug. The bulk powder sale of meprobamate was reserved for Carter, which, through its Wallace Division, sold the drug under the trade name Miltown. American Home Products Corp., through the Wyeth Division, sold meprobamate under a license that it entered into with Carter in 1955 to produce the drug under the brand name Equanil. The price of Miltown was established in line with the competition, determined in April 1955 , and the product was marketed the following month. Carter sold 
Miltown to wholesaler druggists at 5.2 cents a tablet; retail druggists paid the wholesaler 6.5 cents; and the final price to consumers was 10.8 cents per tablet. The price of Miltown remained the same from 1955 to $1960 .^{88}$ Wyeth set identical prices for Equanil, even though it had to make royalty payments of 13 cents to Carter, and its manufacturing costs were much higher than Carter's $(\$ 0.007$ and $\$ 0.015$ per tablet, respectively). ${ }^{89}$

The tactic of big companies in the prescription retail market of pricing the same patented drug at the same level is also found in the third case, in which there were several firms, both large and small, involved in pharmaceutical manufacturing with access to drug powder. The patented drug was marketed under both different brand names and generic names. We find this third scenario in the case of reserpine, a drug patented by Ciba and in which the licensing contract did not include a field-of-use restriction. In other words, Ciba decided to allow its licensees to sell the drug in bulk powder form to small firms. Hence, smaller firms could manufacture their own tablets and capsules, converting the bulk drug into finished packaged tablets (tableting, bottling, packaging, and labeling), and selling them either generically or under their own brand names and at their own prices.

With the drug reserpine, for example, Ciba charged a wholesale price of $\$ 39.50$ per bottle of one thousand (25-milligram) tablets. The final price to the consumer was $\$ 65.83$, given a druggist's mark-up of 40 percent on the selling price. In contrast, some larger manufacturers including Lilly, Merck, Parke, Davis, Squibb, and Upjohn, all of which obtained their licenses from Ciba, sold reserpine at the same price, which was much lower than that charged by Ciba. Smaller firms, with no advertising costs, reduced prices to as much as 90 percent below Ciba's price. The lower costs for smaller firms allowed them to reduce their prices to about $\$ 1.91$ per fifty tablets; Carter's fixed sale price to wholesale druggists, for example, was $\$ 2.60$ per bottle of fifty capsules and \$3.25 to retailers. Some small firms, such as Panray Corporation,

88. Use of Miltown and Equanil fell off dramatically in the early 1960s after news pointed out little reliable evidence for efficacy of these drugs apart from a placebo effect. They were struck from the U.S. Pharmacopeia in 1964. Herzberg, Happy Pills in America, 39. The successor drugs were Librium and Valium, which became available to physicians in the early 1960s.

89. Carter had the product made by five manufacturers of its own selection to whom it imparted its know-how. Most (62 percent) of the bulk that Carter bought was resold to other companies. The price of bulk meprobamate that Wyeth purchased from Carter was $\$ 4.98$ higher than that of Carter's per one thousand tablets (43 percent higher than the price Carter paid for the bulk powder). Carter increased its total profits through extensive royalties. Thus, Wyeth paid Carter \$1.9 million in royalties in 1957 (a royalty of 5 percent of the selling price). "Administered Prices,” 86th Cong., 1960, 2nd session, part 16, at 9,185. 
quoted prices as low as $\$ 2.65$ per bottle of one thousand pills to druggists, given that wholesalers offered a 20 percent reduction to druggists. ${ }^{90}$ However, despite the large difference in the price of the patented reserpine among brand names and unbranded versions (those of small firms), branded products still retained large market shares. ${ }^{91}$ Ciba's Serpasil, for example, was more widely prescribed than reserpine and was the leading brand. However, Panray sold only to institutions and hospitals; it did almost no business with druggists even though its pricing was much lower than Ciba's. ${ }^{92}$

It seems clear that a lower price for a patented drug did not imply higher sales in the retail market, as the case of reserpine illustrates. When a drug group was introduced and received approval from the FDA, some manufacturers fought for a share of the prescription retail market, choosing any method that would establish their trade name in the minds of physicians, as discussed above. Big firms frequently employed this policy to maximize the value of their innovations, thus making it possible to achieve a high degree of market control from the supply side. ${ }^{93}$ However, the high costs of marketing and promoting a drug made it impossible for small sellers of generic-name products to obtain any significant share of the retail prescription market.

Lower prices offered by smaller firms did not jeopardize the licensor's monopoly in the prescription retail market. In this market, most prescriptions were written under branded trade names, even though small firms might sell drugs under generic names at prices that were a fraction of their larger rivals' prices. In the 1950s, big companies made the majority of their revenue and profits in this submarket, in which almost 70 percent of total drug sales occurred. It is evident, however, that although there was no price competition in the retail market, the product rivalry from high levels of investment in $R \& D$ as new products were created, and as incremental advances were introduced, forced the pharmaceutical firms to engage in costly marketing campaigns to increase sales of a particular brand.

\section{Price Competition in the Institutional Market}

Although small companies were unable to gain access to the retail drugstores, because they could neither advertise nor bear the financial costs of detail men-pharmaceutical sales representatives-they

90. “Administered Prices,” Report 448, 87th Congress, 1961, Session 18.

91. There was no competition in prices in the retail market, so royalties were only relevant to obtain more profits.

92. Testimony by Myron Pantzer, president of Panray, "Administered Prices," 86th Cong., 1960, 2nd Session, part 16, at 9,367-9,369 and 9,380.

93. Steele, "Patent Restrictions"; Boldrin and Levine, Against Intellectual Monopoly. 
were nonetheless very active with regard to sales in the institutional market: the Military Medical Supply Agency (MMSA; the central purchasing agent for all hospitals and dispensaries in the Armed Forces), hospitals, cities, and the Veterans Administration. Small companies were serious competitors in this price-sensitive market because of their lower prices. These institutions were required to purchase drugs under generic names at the lowest possible price from any qualified bidder. To be accepted by the government, each manufacturer's product had to meet certain specifications for the particular drug involved. Federal and state agencies had certain quality control procedures, such as inspection of possible suppliers' plants, inspection of manufacturing processes, or random sampling of each lot of drugs for analysis by the FDA. Thus, the government could accept bids by companies selling patented drugs under generic or brand names as long as they were of equal quality.

Institutional buyers usually purchased drugs through a bidding process. The government (federal or state) or a hospital could use two types of solicited bids: a negotiated bid and a competitive or advertised bid. Negotiated bids were usually requested when there was a patented drug product available from only one or very few manufacturers. In this case, there was a chance to negotiate the final price. There was no public opening, and the government contacted each bidder in an attempt to convince that manufacturer that if it reduced the price, it would get a certain amount of business. In a competitive or advertised bid, the government asked for bids on a drug under its generic names. This process was normally used when quality drugs were available from more than one source and there was no room to negotiate the price. With this type of bid, there were specific deadlines by which the bid had to be returned to the purchaser and then there was a public opening, at which time any representative could enter the bidders' room and listen to the bids as they were offered.

To understand whether the inclusion of field-of-use restrictions of patent licensing contracts eroded price competition in the institutional market-that is, by excluding competition from smaller companies-it is important to distinguish the three different scenarios, as those noted above for the prescription retail market, which were dependent on the number of firms compounding finished patented drugs from bulk-powder active ingredients. First, in which there was only one bidder because the only producer of the drug in the United States was the licensee firm (the owner of the patent was a foreign company that did not operate in the United States), it was found that the bidder offered a discount to the institutional buyer as compared to the price offered in the retail market. This happened, for example, with the drug Sparine, which was produced only by 
Wyeth in the United States. Wyeth negotiated a bid to the Veterans Administration (VA) at $\$ 24.51$ per bottle in January 1958 and to the MMSA at $\$ 24.42$ per bottle in April 1958, whereas retail druggists were paying \$32.49. ${ }^{94}$ Similarly, in relation to the product Thorazine, SKF-the only producer of this drug in the United States-offered sales to the federal government at a price lower than that on the retail market. ${ }^{95}$ For example, during the period from 1956 to 1959, the MMSA bought $\$ 2,215,113$ worth of Thorazine from SKF at negotiated prices. In 1956, they twice purchased the 25-milligram dose in bottles of fifty—at $\$ 2.19$ and $\$ 2.21$ - whereas a druggist paid $\$ 3.03$. In 1957, druggists paid $\$ 2.27$ for the same type and dosage of Thorazine. In 1957 , the MMSA made one purchase in the amount of $\$ 33.46$ for the 100-milligram tablet in bottles of five hundred. However, in that year, the price to retail druggists was \$46.32. In 1958 the MMSA made two purchases of the 25-milligram dose in bottles of fifty-at $\$ 2.17$ and at \$2.19. In 1958 the MMSA made one purchase in the amount of $\$ 33.37$ for 100 -milligram tablets in bottles of five hundred. At the same time, the price to retail druggists was \$46.32. In 1959 the MMSA made a purchase for $\$ 20.80$ for 25 -milligram tablets in bottles of five hundred, while the price to retail druggists was $\$ 28.79 .^{96}$

It seems clear from these data that in the first scenario, when there was only one bidder, the government paid a lower price in comparison to the price paid by retail druggists. This reduction was around 25 percent to 30 percent. ${ }^{97}$ There were two main reasons for giving this price discount: the first was that large institutions bought drugs in great quantities, and the second was that distribution expenses, advertising, and selling costs were not a factor in sales to federal or state governments.

In the second scenario, as noted above, there were only a few bidders and the licensing contract included a field-of-use restriction. This was the case with meprobamate. The federal government advertised this drug by the generic name (meprobamate), but in the United States there were only two bidders: Carter, the patent owner,

94. "Administered Prices," 86th Cong., 1960, 2nd Session, part 16, at 8,9678,969 and 9,276-9,277.

95. About 70 percent of the volume of SKF's drugs went to state and federal mental hospitals. Testimony by Walter A. Munns, president of the company, “Administered Prices,” 86th Cong., 1960, 2nd Session, part 16, at 8,927.

96. Regarding the purchases of the drug for intravenous use, in 1956 the MMSA bought two quantities from SKF: one for \$3.16 and another for \$3.17: 25 milligrams. In 1957 the MMSA made one purchase at \$3.27 and another in 1958 in the amount of $\$ 3.12$ for the same product. During this same period, for the same product, SKF charged retail druggists $\$ 4.38$.

97. SKF also made sales to the VA at very similar prices to those offered to the MMSA. 
and Wyeth, the licensee. Carter sold in bulk form to Wyeth, which then tableted, bottled, and labeled it under its own trademark prior to distribution. The MMSA asked for competitive bids, but the outcome was always the same: identical prices but lower than retail prices. Wallace (a division of Carter) and Wyeth bid exactly the same price, so the agency was forced to settle the matter by splitting the awarded contract, drawing lots, or making the decision on the basis of a labor surplus area (see table 4). Henry H. Hoyt, the president of Carter, explained the situation, saying that the firm had a standard price for everyone, from the wholesale druggist in the city, to county and state hospitals, and to military supply depots. The latter two categories received discounts because the orders were placed for large amounts. ${ }^{98}$ The wholesaler who bought meprobamate paid $\$ 3.25$ for a package of fifty while the government paid $\$ 2.50$. The price per tablet to druggists was 6.5 cents and to the MMSA was 5 cents, which was a discount of around 23 percent.

In conclusion, in these first two scenarios-that is, when only one firm or a few firms manufactured a patented drug-either the producer monopolized it or sellers shared the market, respectively. This happened with the patented tranquilizers meprobamate, promazine, and chlorpromazine, purchased by the MMSA at prices that were 25 percent to 35 percent lower than the price to retail druggists.

The third scenario was in which both large and small firms manufactured the patented drug and were able to make bids to institutional buyers. In other words, patent licensing contracts did not include a field-of-use restriction and small firms compounded finished drugs, converting the bulk drug into finished packaged tablets and selling them at their own prices. This is the case with reserpine, a drug developed by Ciba Pharmaceutical Co. but which was widely licensed, allowing the licensees to sell the drug in bulk powder form. Small firms could set lower prices due to their lower manufacturing costs, given that there were no economies of scale in production and they did not have to undertake R\&D or marketing costs in the manufacture of the drug. There were several suppliers that made bids at one time or another. Institutional buyers asked for these bids generically. ${ }^{99}$ The result was

98. The MMSA bought in bottles of five hundred (except in one bid) as opposed to sales to druggists in bottles of fifty. Testimony by Henry H. Hoyt, “Administered Prices," 86th Cong., 1960, 2nd Session, part 16, at 9,185-9,186.

99. In comparing retail druggists' prices to those established under a bid, it was clear that bidders supplying a brand-name drug in a competitive bid were forced to cut their prices significantly more than in a negotiated bid. The reason is that in this bidding process, they were competing with many smaller companies, which forced them to reduce their prices. In cases in which a few companies manufactured the product, the price to the federal government would be just one-sixth or one-fifth of what it was to druggists. 
Table 4. U.S. Military Medical Supply Agency bids on negotiated contracts, 1958-1959, meprobamate, bottles (five hundred tablets)

\begin{tabular}{|c|c|c|c|c|c|}
\hline Date & $\begin{array}{c}\text { Number of } \\
\text { bottles Solicited }\end{array}$ & $\begin{array}{l}\text { Successful } \\
\text { bidder }\end{array}$ & Unit Price & Total price & $\begin{array}{l}\text { Other } \\
\text { bidders }\end{array}$ \\
\hline Jan. 13, 1958 & 13,680 & Wyeth* & 22.5 & 307,800 & Wallace \\
\hline Jan. 21, 1958 & 2,000 & Wallace & $\begin{array}{l}2.5 \text { (it was a } \\
\text { tie bid, small } \\
\text { business)** }\end{array}$ & 5,000 & Wallace \\
\hline Mar. 3, 1958 & 19,200 & Wyeth* & 22.5 (tie bid) & 432,000 & Wallace \\
\hline Apr. 11, 1958 & 19,200 & Split & 22.5 & 432,000 & Wallace \\
\hline Nov. 17, 1958 & 6,000 & Wyeth & 20.25 & 121,500 & Wallace \\
\hline Feb. 5, 1959 & 43,560 & $\begin{array}{c}\text { Wallace (won } \\
\text { by draw) }\end{array}$ & 20.25 & 882,090 & Wallace \\
\hline Apr. 6, 1959 & 22,128 & Wyeth & 20.25 & 448,092 & Wallace \\
\hline Sept. 2, 1959 & 18,768 & Wyeth* & 19.845 & 372,281 & Wallace \\
\hline
\end{tabular}

Source: "Administered Prices," 86th Cong., 1960, 2nd session, part 16, at 9,200.

Note: ${ }^{*}=$ awarded the bid because they were in a labor surplus area. ${ }^{*}=$ in bottles of fifty.

a reduction from 1956 to 1959 in the price for reserpine sold to the MMSA from $\$ 1.39$ to 60 cents, a reduction of more than 60 percent (see table 5). On several occasions, Ciba underbid smaller firms that sold only under the generic name, with the lowest price being offered by Ciba: 60 cents a bottle in February 1959, which was only 1.5 percent of Ciba's price to retail druggists of $\$ 39.90 .{ }^{100}$

Reserpine is the only example in which there was a wide variation in prices in the institutional market, even though it was a patented drug. The reason for this unusual situation is that Ciba, which won the patent, licensed any company that wanted to be licensed. Ciba also allowed the licensees to sell the drug in bulk powder form to small firms that manufactured their own capsules-under their own brand name or more frequently under the generic name-because the licensing contracts did not contain a field-of-use restriction. Thus, small firms broke into the manufacturing process and sold reserpine at lower prices than the large firms. The introduction of more bidders led to substantial price reductions in the institutional market. ${ }^{101}$

In is clear from these data that the lowest bids came from major drug companies supplying brand-name drugs in only two cases: in the first, brand-names were purchased when the proprietary drug was one from the few producers available (a negotiated bid), and the second was when the supplier of the proprietary drug was the lowest bidder.

100. The cost of production of such a bottle was 1.6 percent of the wholesale price.

101. "Administered Prices," 86th Cong., 1960, 2nd Session, part 18, 1960, at 10,595 . 
Table 5. Military Medical Supply Agency orders of reserpine, $25 \mathrm{mg}$., bottles of 1,000

\begin{tabular}{|c|c|c|c|c|c|c|c|}
\hline Date & Type of bid & $\begin{array}{l}\text { Quantity solicited } \\
\text { (no. bottles) }\end{array}$ & $\begin{array}{l}\text { Successful } \\
\text { bidder }\end{array}$ & $\begin{array}{l}\text { Unit price } \\
\text { (dollars) }\end{array}$ & $\begin{array}{c}\text { Total price } \\
\text { (dollars) }\end{array}$ & Other bidders & Price(s)/cents per tablet \\
\hline Feb. 20, 1956 & Advertised & 685 & Eli Lilly & 1.39 & 3,948 & E. R. Squibb & 6.1 \\
\hline Feb. 20, 1956 & Advertised & 2,160 & Eli Lilly & 1.39 & & Smith-Dorsey & 2.57 \\
\hline Feb. 20, 1956 & Advertised & 672 & Eli Lilly & 1.39 & & $\begin{array}{l}\text { Ciba Pharmaceutical } \\
\text { Pitman-Moore Co. }\end{array}$ & $\begin{array}{l}2.04 \\
3.25\end{array}$ \\
\hline Oct. 3, 1956 & Negotiated & 1,080 & Ciba & 1.15 & 2,469 & Lilly & 2.35 \\
\hline Oct. 3, 1956 & Negotiated & 1,224 & Ciba & 1.15 & 2,469 & & \\
\hline Nov. 29,1956 & Advertised & 2,808 & Panray Corp. & 1.10 & 3,088 & $\begin{array}{l}\text { American Pharma Co. } \\
\text { Kasar Co. } \\
\text { Eli Lilly } \\
\text { Merck Sharpe \& Dohme } \\
\text { E. R. Squibb }\end{array}$ & $\begin{array}{l}1.29 / 1.26 / 1.27 \\
2 \\
1.16 \\
1.38 \\
2.35\end{array}$ \\
\hline Feb. 11, 1957 & Negotiated & $\begin{array}{l}2,472 \\
1,656\end{array}$ & $\begin{array}{l}\text { Ciba } \\
\text { Ciba }\end{array}$ & $\begin{array}{l}0,92 \\
0,92\end{array}$ & $\begin{array}{l}3,797 \\
3,797\end{array}$ & $\begin{array}{l}\text { American Pharma Co. } \\
\text { American Pharma Co. } \\
\text { Eli Lilly } \\
\text { Panray Corp. }\end{array}$ & $\begin{array}{l}1.04 \\
1.08 \\
1.22 \\
1.1\end{array}$ \\
\hline Oct. 14,1957 & Negotiated & 3,024 & Ciba & 0.76 & 2,298 & $\begin{array}{l}\text { Brewer \& Co. } \\
\text { Bryant } \\
\text { Eli Lilly } \\
\text { Merit Laboratories }\end{array}$ & $\begin{array}{l}1.39 \\
1.42 \\
1.66 \\
1.7\end{array}$ \\
\hline Jan. 30, 1958 & Negotiated & 6,912 & Panray Corp. & 0.7 & 4,838 & $\begin{array}{l}\text { Bryant } \\
\text { Ciba } \\
\text { Eli Lilly } \\
\text { E. R. Squibb }\end{array}$ & $\begin{array}{l}1.6 \\
0.76 \\
0.773 \\
2.35\end{array}$ \\
\hline
\end{tabular}


Table 5 Continued

\begin{tabular}{|c|c|c|c|c|c|c|c|}
\hline Date & Type of bid & $\begin{array}{l}\text { Quantity solicited } \\
\text { (no. bottles) }\end{array}$ & $\begin{array}{l}\text { Successful } \\
\text { bidder }\end{array}$ & $\begin{array}{l}\text { Unit price } \\
\text { (dollars) }\end{array}$ & $\begin{array}{c}\text { Total price } \\
\text { (dollars) }\end{array}$ & Other bidders & Price(s)/cents per tablet \\
\hline \multirow[t]{11}{*}{ Jun. 20, 1958} & Advertised & 4,200 & $\begin{array}{l}\text { American } \\
\text { Quinine Co }\end{array}$ & 0.65 & 2,772 & American Pharma Co. & 0.84 \\
\hline & & & & $0.67 / 0.7$ & & Brewery Co. & 0.9 \\
\hline & & & & & & Bryant & 1.1 \\
\hline & & & & & & Ciba & 0.7 \\
\hline & & & & & & Eli Lilly & 0,73 \\
\hline & & & & & & Merit Laboratories & $0,93 / 0,89 / 0,97$ \\
\hline & & & & & & Nysco Laboratories & $0,95 / 0,96$ \\
\hline & & & & & & Panray Corp. & 0,7 \\
\hline & & & & & & Premo & 1,79 \\
\hline & & & & & & E. R. Squibb & 2.35 \\
\hline & & & & & & Success Chemical & 0.9 \\
\hline \multirow[t]{10}{*}{ Sep. 1958} & Advertised & 3,432 & Ciba & 0.64 & 2,196 & American Pharma Co. & 0.89 \\
\hline & & & & & & Brewer \& Co. & 0.96 \\
\hline & & & & & & Hamilton-Blair & 1.18 \\
\hline & & & & & & Eli Lilly & 0.738 \\
\hline & & & & & & Merit Laboratories & $0.84 / 0.87 / 0.92 / 0.86 / 0.9$ \\
\hline & & & & & & Nysco Laboratories & 1.2 \\
\hline & & & & & & Panray Corp. & 0.65 \\
\hline & & & & & & Premo & 1.39 \\
\hline & & & & & & E. R. Squibb & 1.72 \\
\hline & & & & & & Strong Cobb & 1.21 \\
\hline \multirow[t]{2}{*}{ Feb. 24, 1959} & Advertised & 3,960 & Ciba & 0.6 & 2,376 & American Pharma Co. & 0.82 \\
\hline & & & & & & American Quinine & $0.65 / 0.63 / 0.68 / 0.64 / 0.67 / 0.66$ \\
\hline
\end{tabular}




\section{Conclusions}

By the late 1950s, Congressional Democrats, the FTC, consumer groups, and some physicians had become preoccupied with the high costs of drugs and the advertising practices of prescription drug firms. In response to these concerns, Senator Kefauver started a Congressional investigation to study the price inflexibility of those firms producing ethical drugs. On May 8, 1961, the Subcommittee on Antitrust and Monopoly of the Senate Judiciary Committee submitted its report on the ethical drugs industry. The report found that monopolistic drug pricing and abuses of patent privilege existed in the U.S. pharmaceutical industry. Kefauver unsuccessfully tried to restrict the use of pharmaceutical patents so as to increase competition and thereby reduce the price of prescription drugs.

In this article, we examined whether patents were employed as a strategy to restrict price competition. We studied the tranquilizer sector in the period when psychopharmacology in the treatment of mental illness really took off. At that time, pharmaceutical firms holding a patent usually decided to include a restrictive clause-a field-of-use restriction-in patent licensing contracts, which allowed licensees to sell only in finished form. In this way, the patent owner prevented small firms from buying bulk sales of the finished powder in order to tablet the powder and sell it, either generically or under their own brand names at lower prices. Smaller firms were able to sell drugs at lower prices because they did not have to recoup extensive R\&D and marketing costs and, therefore, they incurred fewer costs than the big firms.

We found that field-of-use restrictions were used as solutions to exclude price competition from small companies only in the institutional market, in which price competition was extremely important to win a bid. On the one hand, licensing contracts that did not contain field-of-use restrictions allowed the presence of smaller bidders, and so the big companies were forced to enter into price competition and to reduce their prices if they wanted to win a bid. ${ }^{102}$ On the other hand, small sellers could not obtain any significant share of the institutional market if the relevant patent licensing contract included a field-of-use restriction.

By contrast, in the retail segment, those companies that sold patented brand-name tranquilizers were able to maintain their market

102. There are three main reasons why big companies offered low bids to the government: to gain prestige in having their material used by these institutions, to promote a brand to the doctors who worked at these institutions (and who, when they went out and practiced in civilian life, would remember the brand), and to clear excess stock. 
price against a lower-priced drug sold under its generic name. In this submarket, there was no price competition, even when smaller firms were present as competitors. As a consequence, the strategy of including field-of-use restrictions in licensing contracts made no sense in the retail prescription submarket, because the presence of smaller firms selling the same drug at lower prices did not threaten the licensor's monopoly. High advertising and promotional costs prevented price competition from smaller firms in relation to ethical drugs, regardless of the inclusion of field-of-use restrictions in licensing contracts.

Although there was no price competition from small firms selling patented drugs under their generic names in the retail market, competition among patented drugs was a significant issue, because these drugs were often highly substitutable and could compete with one another. In this situation, the big pharmaceutical firms attempted to sell their products in the retail market, not by offering lower prices but by investing large sums in advertising, promotion, and marketing. The high volume of advertising arose from fierce competition among new products due to high rates of product obsolescence and rapidly growing markets. These conditions promoted competition and provided an impetus to innovate. The final aim of promotional activities was to differentiate products from those of competitors and to attract the attention of physicians. This product competition provided a societal benefit: it increased the rate at which firms developed new drugs and accelerated the introduction of improved (though not innovative) drugs, thus providing patients with a greater range of choices. ${ }^{103}$

Finally, we argued that it is not possible to show that monopolies arose from patent privilege, because product competition undoubtedly existed. High prices for patented drugs allowed the financing of sales campaigns due to product rivalry, although with little or no price difference involved. Patented products were often highly substitutable and could thus compete with one another; additionally, patents did not ensure a monopoly position without a significant selling effort. Therefore, advertising was complementary to innovation: competition between identical chemical entities substantially increased the effectiveness of sales efforts in this industry. Thus, we found a positive and increasing feedback between innovation and advertising that was essential to this industry and was particularly significant in the case of tranquilizers. Pharmaceutical firms used patents and complementary heavy investment in promotion and marketing as a strategy for increasing their market share and to combat competition from ethical drugs that were chemically different yet offered comparable therapies.

103. Lee, “"Me-too’ Products.” 
Bibliography of Works Cited

\section{Books}

Boldrin, Michele, and David K. Levine. Against Intellectual Monopoly. Cambridge: Cambridge University Press, 2008.

Carpenter, Daniel. Reputation and Power: Organizational Image and Pharmaceutical Regulation at the FDA. Princeton, NJ: Princeton University Press, 2010.

Chandler, Alfred D. Shaping the Industrial Century: The Remarkable Story of the Evolution of the Modern Chemical and Pharmaceutical Industries. Cambridge, MA: Harvard University Press, 2005.

Contractor, Farok J. Licensing in International Strategy. Westport, CT: Quorum Books, 1985.

Gambardella, Alfonso. Science and Innovation: The US Pharmaceutical Industry During the 1980s. Cambridge: Cambridge University Press, 1995.

Gaudillière, Jean Paul, and Ulrike Thoms. The Development of Scientific Marketing in the Twentieth Century: Research for Sales in the Pharmaceutical Industry. London: Routledge, 2015.

Greene, Jeremy A. Generic: The Unbranding of Modern Medicine. Baltimore, MD: The Johns Hopkins University Press, 2014.

- Prescribing by Numbers: Drugs and the Definitions of Disease. Baltimore, MD: The Johns Hopkins Press, 2007.

Greene, Jeremy A., and E. Siegel Watkins, eds. Prescribed: Writing, Filling, Using, and Abusing the Prescription in Modern America. Baltimore, MD: The Johns Hopkins University Press, 2012.

Harris, Richard. The Real Voice. New York: Macmillan, 1964.

Healy, David. The Antidepressant Era. Cambridge, MA: Harvard University Press, 1997.

- The Creation of Psychopharmacology. Cambridge, MA: Harvard University Press, 2002.

- Let Them Eat Prozac: The Unhealthy Relationship Between the Pharmaceutical Industry and Depression. New York: New York University Press, 2004.

Herzberg, David. Happy Pills in America: From Miltown to Prozac. Baltimore, MD: The Johns Hopkins University Press, 2009.

Liebenau, Jonathan. Medical Science and Medical Industry: The Formation of the American Pharmaceutical Industry. Baltimore, MD: The Johns Hopkins University Press, 1987.

Mahoney, Tom. The Merchants of Life. New York: Harper and Brothers, 1959.

Marks, Harry M. Progress of Experiment: Science and Therapeutic Reform in the United States, 1900-1990. Cambridge: Cambridge University Press, 1997.

Metzl, Jonathan. Prozac on the Couch: Prescribing Gender in the Era of Wonder Drugs. Durham, NC: Duke University Press, 2003.

Mintz, Morton. The Therapeutic Nightmare. Boston, MA: Houghton Mifflin, 1965. 
Rasmussen, Nicolas. On Speed: The Many Lives of Amphetamine. New York: New York University Press, 2008.

Schwartzman, David. Innovation in the Pharmaceutical Industry. Baltimore, MD: The Johns Hopkins University Press, 1976.

Shorter, Edward. A History of Psychiatry: From the Era of the Asylum to the Age of Prozac. Oxford: John Wiley \& Sons, 1997.

Silberston, Zangwill Aubrey. The Economic Importance of Patents. London: Common Law Institute of Intellectual Property, 1987.

Silverman, Milton. The Drugging of the Americas. Berkeley: University of California Press, 1976.

Silverman, Milton, and Philip R. Lee. Pills, Profits \& Politics. Berkeley: University of California Press, 1974.

Smith, Mickey C. A Social History of the Minor Tranquilizers: The Quest for Small Comfort in the Age of Anxiety. Santa Barbara, CA: Greenwood Publishing Group, 1991.

Swazey, Judith. Chlorpromazine in Psychiatry: A Study of Therapeutic Innovation. Cambridge, MA: MIT Press, 1974.

Taylor, Christopher T., and Z. Aubrey Silberston. The Economic Impact of the Patent System. Cambridge: Cambridge University Press, 1973.

Temin, Peter. Taking Your Medicine: Drug Regulation in the United States. Cambridge, MA: Harvard University Press, 1980.

Tobbell, Dominique. Pills, Power, and Policy: The Struggle for Drug Reform in Cold War America and Its Consequences. Berkeley: University of California Press/Milbank Books on Health and the Public, 2012.

Tone, Andrea. The Age of Anxiety: A History of America's Turbulent Affair with Tranquilizers. New York: Basic Books, 2009.

Williamson, James R. Federal Antitrust Policy during the Kennedy-Johnson Years. Westport, CT: Praeger Publishers, 1995.

\section{Articles and Chapters in Books}

Achilladelis, Basil, and Nicholas Antonakis. "The Dynamics of Technological Innovation: The Case of the Pharmaceutical Industry." Research Policy 30 (2001): 535-588.

Arora, Ashish. "Patents, Licensing, and Market Structure in the Chemical Industry." Research Policy 26, no. 4 (1997): 391-403.

Arrow, Kenneth J. "Economic Welfare and the Allocation of Resources for Invention." In The Rate and Direction of Inventive Activity: Economic and Social Factors, edited by Universities-National Bureau Committee for Economic Research, Committee on Economic Growth of the Social Science Research Council, 609-626. Princeton, NJ: Princeton University Press, 1962.

Bachrach, Leona L. "The State of the State Mental Hospital at the Turn of the Century." New Directions for Mental Health Services 91 (2001): 89-106.

Ban Thomas, A. "Fifty Years Chlorpromazine: A Historical Perspective." Neuropsychiatric Disease \& Treatment 3, no. 4 (2007): 495-500.

Bud, Robert. "Antibiotics, Big Business, and Consumers: The Context of Government Investigations Into the Postwar American Drug Industry." Technology and Culture 46, no. 2 (2005): 329-349. 
Clarkson, Kenneth W. "The Use of Pharmaceutical Profitability Measures for Public Policy Actions." In Issues in Pharmaceutical Economics, edited by Robert L. Chien, 105-124. Lexington, MA: Lexington Books, 1979.

Comanor, William S. "Research and Competitive Product Differentiation in the Pharmaceutical Industry in the United States." Economica 31, no. 124 (1964): 372-384.

— . "The Political Economy of the Pharmaceutical Industry." Journal of Economic Literature 24 (September 1986): 1178-1217.

David, Paul, Dominique Foray, and W. Edward Steinmueller. "The Research Network and the New Economics of Science: From Metaphor to Organizational Behaviours." In The Organization of Economic Innovation in Europe, edited by A. Gambardella and F. Malerba, 303-342. Cambridge: Cambridge University Press, 1999.

Donohue, Julie. "History of Drug Advertising: The Evolving Roles of Consumers and Consumer Protection." Milbank Quarterly 84, no. 4 (2006): 659-699.

Ellison, Glenn, and Sara F. Ellison. "Strategic Entry Deterrence and the Behavior of Pharmaceutical Incumbents Prior to Patent Expiration." American Economic Journal: Microeconomics 3, no. 1 (2011): 1-36.

Faunce, T., and J. Lexchin. "'Linkage’ Pharmaceutical Evergreening in Canada and Australia." Australia and New Zealand Health Policy 4, no. 8 (2007): $1-11$.

Gallini, Nancy. "Deterrence by Market Sharing: A Strategic Incentive for Licensing." American Economic Review 74 (1984): 931-941.

—. "The Economics of Patents: Lessons from Recent US Patent Reform." Journal of Economic Perspectives 16, no. 2 (2002): 131-154.

Gaudillière, Jean Paul. "From Propaganda to Scientific Marketing: Schering, Cortisone, and the Construction of Drug Markets." History and Technology 29, no. 2 (2013): 188-209.

—. "Marketing Loops: Clinical Research, Consumption of Antidepressants and the Reorganization of Promotion at Geigy in the 1960s and 1970s." In The Development of Scientific Marketing in the Twentieth Century: Research for Sales in the Pharmaceutical Industry, edited by Jean Paul Gaudillière and Ulrike Thoms, 167-190. London: Routledge, 2015.

Grabowski, Henry G., and John M. Vernon. "Substitution Laws and Innovation in the Pharmaceutical Industry." Law Contemporary Problems 43, no. 1 (Winter-Spring 1979): 43-66.

Greene, Jeremy A. "Attention to 'Details': Etiquette and the Pharmaceutical Salesman in Postwar American." Social Studies of Science 34, no. 2 (2004): 271-292.

Greene, Jeremy A., and Scott H. Podolsky. "Keeping Modern in Medicine: Pharmaceutical Promotion and Physician Education in Postwar America." Bulletin of the History of Medicine 83, no. 2 (2009): 331-377.

—. "Reform, Regulation, and Pharmaceuticals-The Kefauver-Harris Amendments at 50." New England Journal of Medicine 367 (2012): 1481-1483.

Gronfein, William. "Psychotropic Drugs and the Origins of Deinstitutionalization.” Social Problems 32, no. 5 (1985): 437-454. 
Harcourt, Bernard E. "Reducing Mass Incarceration: Lessons from the Deinstitutionalization of Mental Hospitals in the 1960s." Ohio State Journal of Criminal Law 53 (2011): 53-88.

Henderson, R., L. Orsenigo, and G. P. Pisano. "The Pharmaceutical Industry and the Revolution in Molecular Biology: Exploring the Interaction between Scientific, Institutional and Organizational Change." In The Sources of Industrial Leadership, edited by D. Mowery and R. R. Nelson, 267-311. Cambridge: Cambridge University Press, 1999.

Herzberg, David. "Busted for Blockbusters. 'Scrip Mills?' Quaalude, and Prescribing Power in the 1970s." In Prescribed: Writing, Filling, Using, and Abusing the Prescription in Modern America, edited by Jeremy A. Greene and E. Siegel, 207-231. Watkins. Baltimore, MD: The Johns Hopkins University Press, 2012.

Ignaciuk, Agata, Teresa Ortiz-Gómez, and Esteban Rodriguez-Ocaña. "Doctors, Women and the Circulation of Knowledge of Oral Contraceptives in Spain, 1960s-1970s." In Gendered Drugs and Medicine: Historical and SocioCultural Perspectives, edited by Teresa Ortiz-Gómez and María Jesús Santesmases, 133-152. Burlington, VT: Ashgate Publishing, 2014.

Katz, Michael L., and Carl Shapiro. "How to License Intangible Property." Quarterly Journal of Economics 101 (1986): 567-589.

Kendall, K. W., Simon Ng, and Bertram Schoner. "Consumer Responses to Generic/Chemically Equivalent Drugs." Journal of Public Policy and Marketing 10, no. 2 (1991): 182-201.

Kessel, Nils. "Beyond Innovation: Pharmaceutical Marketing, Market Structure and the Importance of the Old in West Germany, 1950-70." In The Development of Scientific Marketing in the Twentieth Century: Research for Sales in the Pharmaceutical Industry, edited by Jean Paul Gaudillière and Ulrike Thoms, 15-28. London: Routledge, 2015.

—. "'Doriden von Ciba': Sleeping Pills, Pharmaceutical Marketing, and Thalidomide, 1955-1963." History and Technology 29, no. 2 (2013): 191-205.

Kremer, Michael. "Patent Buyouts: Mechanisms for Encouraging Innovation." Quarterly Journal of Economics 113, no. 4 (1998): 1137-1167.

Lall, Sanjaya. "International Pharmaceutical Industry and Less-Developed Countries: I: Oligopolistic Power of Leading Firms." Economic and Political Weekly 9, no. 47 (1974): 1947-1958.

- "Price Competition and the International Pharmaceutical Industry." Oxford Bulletin of Economics and Statistics 40 (1978): 9-21.

Lanjouw, Jean O., and Mark Schankerman. "Protecting Intellectual Property Rights: Are Small Firms Handicapped?" Journal of Law and Economics 47 (2004): 45-74.

Laties, Victor G., and Bernard Weiss. "A Critical Review of the Efficacy of Meprobamate (Miltown, Equanil) in the Treatment of Anxiety." Journal of Chronic Diseases 7, no. 6 (1978): 500-519.

Lee, Thomas H. "Me-too Products: Friend or Foe?" New England Journal of Medicine 350 (2004): 211-212.

Leffler, Keith B. "Persuasion or Information? The Economics of Prescription Drug Advertising." Journal of Law and Economics 24 (1981): 45-74. 
Levin, Richard C., Alvin K. Klevorick, Richard R. Nelson, and Sidney G. Winter. "Appropriating the Returns from Industrial Research and Development.” Brookings Papers on Economic Activity 3 (1987): 783-832.

Liebenau, Jonathan. "Patents and the Chemical Industry: Tools of Business Strategy." In The Challenge of New Technology: Innovation in British Business Since 1850, edited by Jonathan Liebenau, 133-150. Aldershot, UK: Gower, 1988.

López-Muñoz, Francisco, Cecilio Alamo, Eduardo Shen Cuenca, Patrick Winston W. Clervoy, and Gabriel Rubio. "History of the Discovery and Clinical Introduction of Chlorpromazine." Annals of Clinical Psychiatry 17, no. 3 (2005): 113-135.

Mansfield, Edwin. "Patents and Innovation: An Empirical Study." Management Science 32, no. 2 (1986): 173-181.

Marks, Harry M. "Making Risks Visible: The Science, Politics and Regulation of Adverse Drug Reactions." In Ways of Regulating: Therapeutic Agents Between Plants, Shops and Consulting Rooms, edited by Jean Paul Gaudillière and Volker Hess, 105-122. Berlin, Germany: Max-Planck Institute, 2009.

Mechanic, David, and David A. Rochefort. "Deinstitutionalization: An Appraisal of Reform." Annual Review of Sociology 16 (1990): 301-327.

Meurer, Michael J. "The Settlement of Patent Litigation." RAND Journal of Economics 20, no. 1 (1989): 77-91.

Munos, Bernard. "Lessons from 60 years of Pharmaceutical Innovation." Nature Reviews Drug Discovery 8 (2009): 959-968.

Penin, Julien. "Patents Versus Ex Post Rewards: A New Look." Research Policy 34 (2005): 641-156.

Polanyi, Michael. "Patent Reform." Review of Economic Review 11 (1944): 61-76.

Quirke, Viviane. "The Material Culture of British Pharmaceutical Laboratories in the Golden Age of Drug Discovery (c. 1935-75)." International Journal for the History of Engineering \& Technology 79, no. 2 (2009): 280-299.

—. "From Alkaloids to Gene Therapy: A Brief History of Drug Discovery in the 20th Century." In Making Medicines: A Brief History of Pharmacy and Pharmaceuticals, edited by Stuart Anderson, 177-201. London: Pharmaceutical Press, 2005.

Rasmussen, Nicolas. "Making the First Anti-Depressant: Amphetamine in American Medicine, 1929-1950." Journal of the History of Medicine and Allied Sciences 61, no. 3 (2006): 288-323.

Rockett, Katharine E. "Choosing the Competition and Patent Licensing." RAND Journal of Economics 21, no. 1 (1990): 161-171.

Sarett, Lewis H. "FDA Regulations and Their Influence on Future R and D." Research Management 27 (March 1974): 18-20.

Scroop, Daniel. "A Faded Passion? Estes Kefauver and the Senate Subcommittee on Antitrust and Monopoly." Business and Economic History On-Line 5 (2007): 1-17.

Slinn, Judy. "The Development of the Pharmaceutical Industry." In Making Medicines: A Brief History of Pharmacy and Pharmaceuticals, edited by Stuart Anderson, 155-176. London: Pharmaceutical Press, 2005. 
. "Price Controls or Control Through Prices? Regulating the Cost and Consumption of Prescription Pharmaceuticals in the UK, 1948-67." Business History 47, no. 3 (2005): 352-366.

. "Patents and the UK Pharmaceutical Industry Between 1945 and the 1970s." History and Technology 24, no. 2 (2008): 191-205.

Statman, Meir. "The Effect of Patent Expiration on the Market Position of Drugs." In Drugs and Health: Issues and Policy Objectives, edited by Robert B. Helms, 140-151. Washington, DC: American Enterprise Institute, 1981.

Statman, Meir, and Tyzoon Tyebjee. "Strategic Responses to Changes in Public Policy: The Case of the Pharmaceutical Industry and Drug Substitution Laws." Journal of Public Policy and Marketing 3, no. 1 (1984): 99-112.

—. "Trademarks, Patents, and Innovation in the Ethical Drug Industry." Journal of Marketing 45, no. 3 (1981): 71-81.

Steele, Henry. "The Fortunes of Economic Reform Legislation: The Case of the Drug Amendments Act of 1962." American Journal of Economics and Sociology 25, no. 1 (January 1966): 39-51.

—. "Monopoly and Competition in the Ethical Drugs Market." Journal of Law and Economics 5, no. 1 (1962): 131-163.

—. "Patent Restrictions and Price Competition in the Ethical Drugs." Journal of Industrial Economics 12, no. 3 (1964): 198-223.

Stiglitz, Joseph E. "Give Prizes not Patents.” New Scientist 21 (September 16, 2006): 21.

Swann, John P. "FDA and the Practice of Pharmacy: Prescription Drug Regulation before the Durham-Humphrey Amendment of 1951." Pharmacy in History 36, no. 2 (1994): 55-70.

Temin, Peter. "The Origin of Compulsory Drug Prescription." Journal of Law and Economics 22, no. 1 (1979a): 91-105.

. "Technology, Regulation, and Market Structure in the Modern Pharmaceutical Industry.” Bell Journal of Economics 10, no. 2 (1979): 427-446.

Thoms, Ulrike. "The Contraceptive Pill, the Pharmaceutical Industry and Changes in the Patient-Doctor Relationship in West Germany." In Gendered Drugs and Medicine: Historical and Socio-Cultural Perspectives, edited by Teresa Ortiz-Gómez and María Jesús Santesmases, 153-176. Burlington, VT: Ashgate Publishing, 2014.

—. "Standardizing Selling: Pharmaceutical Marketing, the Pharmaceutical Company and the Marketing Expert (1900-1980)." History and Technology 29, no. 2 (2013): 169-187.

Tobbell, Dominique. "Allied Against Reform: Pharmaceutical IndustryAcademic Physician Relations in the United States, 1945-1970.” Bulletin of the History of Medicine 82, no. 4 (2008): 878-912.

—. "Pharmaceutical Politics and Regulatory Reform in Postwar America." In What's Good for Business, edited by Kim Phillips Fein and Julian E. Zelizer, 123-139. Oxford: Oxford University Press, 2012.

—. "'Who's Winning the Human Race?' Cold War as Pharmaceutical Political Strategy." Journal of the History of Medicine and Allied Sciences 64, no. 4 (2009): 429-473. 
Tone, Andrea. "Making of Miltown." In The Age of Anxiety: A History of America's Turbulent Affair with Tranquilizers, edited by Andrea Tone, 2752. New York: Basic Books, 2009.

. "Tranquilizers on Trial: Psychopharmacology in the Age of Anxiety." In Medicating Modern America: Prescription Drugs in History, edited by Andrea Tone and Elizabeth Siegel Watkins, 156-180. New York: New York University Press, 2007.

Wright, Brian D. "The Economics of Invention Incentives: Patents, Prizes, and Research Contracts.” American Economic Review 73 (1983): 691-707.

\section{Reports and Dissertations}

Bond, Ronald S., and F. David. Lean Economic Report on Sales, Promotion, and Product Differentiation in Two Prescription Drug Markets. Staff Report to the Federal Trade Commission, Bureau of Economics, 1977. https://www.ftc. gov/sites/default/files/documents/reports/sales-promotion-and-productdifferentiation-two-prescription-drug-markets/197702salespromo.pdf.

McFadyen, Richard E. "Estes Kefauver and the Drug Industry." Ph.D. diss., Emory University, 1973.

Moon, Nathan William. "The Amphetamine Years: A Study of the Medical Applications and Extramedical Consumption of Psychostimulant Drugs in the Postwar United States, 1945-1980." Ph.D. diss., Georgia Institute of Technology, 2009.

\section{Government Publications}

United States Senate. “Administered Prices in the Drug Industry.” Hearings before the Subcommittee on Antitrust and Monopoly, Senate Committee on the Judiciary, 86th Congress, 2nd Session, Washington, DC, 1960.

—. "Administered Prices in the Drug Industry." Report 448. Hearings before the Subcommittee on Antitrust and Monopoly, Senate on the Judiciary, 87th Congress, 1st session, Washington, DC, 1961. 